\title{
El Tribunal Administrativo del Deporte de Andalucía y la solución de los litigios deportivos $^{1}$
}

\author{
Eloisa Carbonell Porras
}

Catedrática de Derecho Administrativo

Universidad de Jaén

\begin{abstract}
SUMARIO. I. INTRODUGCIÓN. II. LA SUSTITUCIÓN DE LOS REGURSOS ADMINISTRATIVOS ORDINARIOS POR OTROS MECANISMOS: 1. Planteamiento 2. Los criterios del artículo 112. 2 LPAC. III. EL TRIBUNAL ADMINISTRATIVO DEL DEPORTE ESTATAL COMO EJEMPLO DE LA SUSTITUCIÓN DE LOS REGURSOS ADMINISTRATIVOS ORDINARIOS. IV. EL TRIBUNAL ADMINISTRATIVO DEL DEPORTE EN ANDALUCÍA, ¿SUSTITUCIÓN DE LOS RECURSOS ADMINISTRATIVOS ORDINARIOS?: 1. Creación, naturaleza jurídica y puesta en funcionamiento. 2. Composición, organización interna y funcionamiento. 3. Las competencias: A. Generalidades. B. La resolución de recursos contra los actos federativos en el ejercicio de las funciones públicas delegadas. C. La resolución de recursos en los procesos electorales federativos y otras competencias en materia electoral. D. La función consultiva. E. El ejercicio de las potestades sancionadora y disciplinaria. F. La solución de cuestiones litigiosas a través del sistema arbitral o de mediación. $\mathrm{G}$. La resolución de conflictos entre federaciones o sus órganos disciplinarios. H. El conocimiento y la resolución de cualquier otra acción u omisión, la atribución de nuevas competencias y el ejercicio de competencias delegadas $\mathrm{V}$. ALGUNA REFLEXIÓN FINAL. VI. BIBLIOGRAFÍA.
\end{abstract}

1 Este trabajo ha sido realizado en el marco del Proyecto I+D+i del Plan Nacional, Las Entidades locales, sus relaciones y competencias. Realidad, efectos y consecuencias de la racionalización y sostenibilidad financiera en clave nacional y europea (DER2016-74843-C3-1-R), del que soy Investigadora Principal, que se desarrolla en el Grupo de Investigación del Plan Andaluz de Investigación, Desarrollo e Innovación (PAIDI) SEJ-317, «El Derecho Público y la crisis institucional y económica». También deben tenerse en cuenta el Grupo de Excelencia de la Universidad Rey Juan Carlos, «Derecho y política económica» (GEDPE), y el Grupo de Investigación de la Universidad Complutense de Madrid 931089, «Las transformaciones del Estado y la autonomía local: organización institucional, servicios públicos y democracia participativa», en los que colaboro como miembro externo. 
RESUMEN: La legislación deportiva se ha caracterizado por atribuir la resolución de las reclamaciones a órganos colegiados excluidos de la subordinación jerárquica que caracteriza la organización administrativa, antes incluso de que la legislación de procedimiento administrativo común regulará con carácter general la sustitución de los recursos administrativos ordinarios por la revisión mediante órganos colegiados de expertos. Sobre la base de la regulación general del artículo 112, 2 de la Ley 39/2015, se analiza el régimen general del Tribunal Administrativo del Deporte estatal y más específicamente las previsiones de la Ley del Deporte de Andalucía de 2016 respecto del Tribunal Administrativo del Deporte de Andalucía.

PALABRAS CLAVE: recursos administrativos, órganos administrativos de expertos, tribunales administrativos del deporte.

ABSTRACT: Sports regulation has been characterized by conferred the claimsettlement to collegiate body not subject on hierarchical submission within administrative organization, even before the common procedure administrative law had a general regulation about the replacement of the regular administrative review by administrative body of experts special review. Following the Law 39/2015, art. 112. 2, ist analysed the general regime of the state Administrative Sports Tribunal and specifically Andalusian Administrative Sports Tribunal, as ist regulated in the 2016 Andalusia Sports Law.

KEY WORDS: administrative review; administrative body of experts; sports administrative tribunals.

\section{INTRODUCGIÓN}

La necesidad de articular mecanismos que permitan resolver los conflictos eludiendo los procesos judiciales se ha revitalizado en los últimos tiempos ante el aumento de asuntos litigiosos en una sociedad tan compleja como la actual. Para referirse al conjunto de mecanismos de solución de controversias al margen de los tribunales de justicia se suelen emplear el acrónimo «ADR» derivado de las siglas de la expresión en inglés, Alternative Dispute Resolutions². La Unión Europea ha contribuido decisivamente a impulsar estos procedimientos con la aprobación de la Directiva 2008/52/ CE, del Parlamento Europeo y del Consejo, de 21 de mayo, sobre ciertos aspectos de

2 Generalmente se hace referencia al Derecho anglosajón como precursor de vías alternativas al proceso judicial para resolver los conflictos con las Administraciones públicas. Pionera al respecto es la aprobación en Estados Unidos de la Administrative Dispute Resolution Act de 1990, que modificaba la Federal Administrative Procedure Act de 1946 para reforzar el papel de los Administrative Law fudges, como tuve ocasión de analizar en «Los procedimientos administrativos en Estados Unidos», en Agencias y Procedimiento administrativo en Estados Unidos de América, 1996, págs. 52-53 y 84-86. 
la mediación en asuntos civiles y mercantiles, que fue implementada en nuestro país por el Real Decreto-ley 5/2012, de 5 de marzo, transformado en la Ley 5/2012, de 6 de julio, de mediación en asuntos civiles y mercantiles, pero que no resulta de aplicación a las Administraciones públicas. Para resolver los conflictos con la Administración generalmente hay que interponer primero un recurso administrativo y, si no se satisfacen las pretensiones, el recurso contencioso-administrativo, aunque la agilidad y eficacia de estas acciones ha sido cuestionada desde siempre. Por ello, también en las relaciones jurídico-administrativas, se ha defendido la necesidad de incorporar mecanismos alternativos de resolución de conflictos ${ }^{3}$. Así lo reclama la exposición de motivos de la Ley 29/1998, de 13 de julio, reguladora de la jurisdicción contencioso-administrativa («el control de la legalidad de las actividades administrativas se puede y debe ejercer asimismo por otras vías complementarias de la judicial, que sería necesario perfeccionar para evitar la proliferación de recursos innecesarios y para ofrecer fórmulas poco costosas y rápidas de resolución de numerosos conflictos») y lo ha defendido el Consejo de Europa en la Recomendación Rec. (2001) 9, del Comité de Ministros, de 5 de septiembre de 2001, sobre métodos alternativos de resolución de conflictos entre las autoridades administrativas y las personas privadas, que, no obstante, incluye a los recursos administrativos entre las posibles vías alternativas ${ }^{4}$.

El principio de legalidad que rige la actuación de las Administraciones públicas dificulta, como es sabido, el empleo generalizado de las vías alternativas de resolución de conflictos. Por eso, su implantación es muy limitada, debiéndose acudir por lo común a la interposición de los recursos administrativos y contencioso-administrativo que en cada caso procedan. Sí se han producido avances en los litigios que enfrentan a las organizaciones públicas y su diferente entendimiento de la legalidad

3 La preocupación por establecer mecanismos más eficaces que los tradicionales recursos administrativos se refleja en la especial atención que le ha prestado la Asociación Española de Profesores de Derecho Administrativo en sus últimos Congresos, y en sus actas pueden encontrarse las reflexiones doctrinales sobre los problemas existentes y sus posibles soluciones: Las vías administrativas de recurso a debate, Actas del XI Congreso de la Asociación Española de Profesores de Derecho Administrativo celebrado en Zaragoza, los días 5 y 6 de febrero de 2016, y Las prestaciones patrimoniales públicas no tributarias y la resolución extrajudicial de conflictos, Actas del X Congreso de la Asociación Española de Profesores de Derecho Administrativo celebrado en Madrid, los días 6 y 7 de febrero de 2015, ambas editadas por el Instituto Nacional de Administración Pública. Este Instituto también ha publicado la obra Control administrativo y justicia, 2016, que recopila las comunicaciones y ponencias del Seminario celebrado en junio de 2015 bajo la dirección de J. Agudo González.

4 Esta recomendación invoca las anteriores recomendaciones (81)7, sobre el acceso a la Justicia que propone incentivar la conciliación de las partes y el arreglo amistoso de las controversias antes de cualquier proceso judicial así como en los procedimientos en curso, y (86)12, sobre la resolución amistosa de las controversias, cualquiera que sea el orden jurisdiccional, antes o durante el procedimiento judicial. La recomendación (2001)9 se refiere a las siguientes vías para eludir el proceso judicial: Internal reviews, Conciliation and Mediation, Negotiated Settlement, Arbitration. 
o de los intereses públicos. Así, de acuerdo con el artículo 33 de la Ley Orgánica del Tribunal Constitucional, antes de la interposición del recurso de inconstitucionalidad por el Presidente del Gobierno y los órganos ejecutivos autonómicos, puede negociarse en la Comisión Bilateral de Cooperación entre la Administración General del Estado y la respectiva Comunidad Autónoma que hoy contempla el art. 153 de la Ley 40/2015, de 1 de octubre de 2015, de régimen jurídico del sector público (en adelante, LRJSP) para intentar resolver las discrepancias, evitando, en su caso, el recurso. También cabe recordar ahora la Disposición adicional única de la Ley 11/2011, de 20 de mayo, de reforma de la Ley 60/2003, de 23 de diciembre, de Arbitraje y de regulación del arbitraje institucional en la Administración General del Estado, que articula un procedimiento para resolver las controversias jurídicas relevantes que se susciten entre la Administración del Estado y sus entes instrumentales. Se atribuye la resolución de la controversia a la Comisión Delegada del Gobierno para la Resolución de Controversias Administrativas, que estará presidida por el Ministro de la Presidencia y se integrará por los Ministros de Economía y Hacienda y de Justicia, que serán vocales natos, y por el Ministro o Ministros afectados, en los términos que determine un reglamento pendiente de aprobación ${ }^{5}$. Por otra parte, en los conflictos entre las Administraciones estatal y autonómica con las Entidades Locales la Ley 7/1985, de 2 de abril, reguladora de las bases de régimen local regula un requerimiento previo al recurso contencioso-administrativo que después se ha generalizado para todos los litigios interadministrativos en el artículo 44 de la LJCA; este requerimiento sustituye a los recursos administrativos y precisamente tiene como

\footnotetext{
Este régimen se aplicará a las controversias jurídicas relevantes (que tengan una cuantía económica de al menos 300.000 euros o que, a juicio de una de las partes, sea de esencial relevancia para el interés público) que se susciten entre la Administración General del Estado y sus organismos públicos (incluidas las Entidades Gestoras y Servicios Comunes de la Seguridad Social), o entre dos o más de estas entidades públicas, así como a las que se susciten entre las sociedades mercantiles estatales y las fundaciones del sector público estatal con su Ministerio de tutela, la Dirección General de Patrimonio o los organismos o entidades públicas que ostenten la totalidad del capital social o dotación de aquellas, salvo que se establezcan mecanismos internos de resolución de controversias. Este régimen se ha calificado como arbitraje institucional o interadministrativo. Pero, a mi juicio, no hay intervención de un tercero sino la articulación de un procedimiento administrativo que soluciona un conflicto entre entidades públicas que no podría residenciarse ante la jurisdicción contencioso-administrativa pues el artículo 20 LJCA, prohíbe expresamente que los entes instrumentales interpongan recurso contencioso-administrativo contra la Administración pública de la que dependen, salvo que la Ley les haya dotado de un estatuto específico de autonomía respecto de dicha Administración. Sobre este régimen puede verse M. García Peréz, «Luces y sombras del arbitraje institucional en la Administración General del Estado» en RAAP, nº. 80, 2011, pág. 81 ss; y V. Escartín Escudé, «El arbitraje y otros medios de resolución de conflictos el Derecho administrativo», en Revista Aragonesa de Administración Pública, nsº. 39-40, 2012, págs. 152 y ss.
} 
finalidad eludir la interposición del recurso contencioso-administrativo o, en su defecto, precisar los términos del enfrentamiento ${ }^{6}$.

En lo que a los conflictos entre Administración y ciudadanos se refiere, las posibilidades que ofrece la legislación vigente no han tenido un amplio desarrollo ${ }^{7}$. Respecto de las vías de carácter intrajudicial, el artículo 77 LJCA admite el acuerdo entra las partes que ponga fin a la controversia cuando el juicio se promueva sobre materias susceptibles de transacción y en particular sobre estimación de cantidad. En fase administrativa, la Ley 39/2015, de 1 de octubre, del Procedimiento Administrativo Común de las Administraciones Públicas (en adelante, LPAC) mantiene las mismas posibilidades para resolver los conflictos que su antecesora, la Ley 30/1992, y , por tanto, nada se ha avanzado en esta línea. Como es sabido, el art. 86 LPAC (como el art. 88 Ley 30/1992) prevé que las Administraciones Públicas celebren acuerdos, pactos o convenios con personas de derecho público o privado para satisfacer el interés público que tienen encomendado, siempre que no sean contrarios al ordenamiento jurídico ni versen sobre materias no susceptibles de transacción, que pondrán fin al procedimiento administrativo o se insertarán en el mismo con carácter previo, vinculante o no, a la resolución que le ponga fin. De esta forma y sin perjuicio de las dificultades de su aplicación, la Ley da cobertura a mecanismos de solución de controversias antes de que la Administración adopte una decisión unilateral $^{8}$. Se trata de una vía previa y, por ello, diferente a la de los recursos admi-

\footnotetext{
$6 \quad$ Vid. E. Carbonell Porras, «El Conflicto interadministrativo local: novedades en la LRBRL y en la LJCA», en $\mathcal{f A}$ n $^{\circ}$ 1, 2000, págs. 149 ss; y «Artículos 63 a 67», en Comentarios a la Ley Reguladora de las Bases de Régimen Local, 2007, pág. 1523 y 1558.

No obstante desde el Consejo General del Poder Judicial se quiere potenciar otros medios de resolución de controversias como es la mediación. Al respecto puede verse la Guía para la práctica de la mediación intrajudicial elaborada por el Consejo disponible en la web (http://www.poderjudicial.es /cgpj/ es/Temas/Mediacion/ Guia- para-la-practica-de-la- Mediacion- Intrajudicial/), que incluye un protocolo de mediación contencioso-administrativa (pág. 165 ss). Sobre la mediación en el ámbito administrativo, puede verse con carácter general A. Masucci, «El procedimiento de mediación como medio alternativo de resolución de litigios en el Derecho administrativo. Esbozo de las experiencias francesa, alemana e inglesa», en $R A P \mathrm{n}^{\circ} .178$ (2009), pág. 9 ss; así como G. Carballo Martínez, «La mediación administrativa. Algunas propuestas para su implementación en el régimen jurídico administrativo y procesal» y $\mathrm{M}^{\mathrm{a}}$. $\mathrm{C}$. García Vicario, «La mediación como sistema alternativo y complementario de resolución de conflictos en la Jurisdicción Contencioso-Administrativa», ambos en RfCL, nº. 29, 2013.

8 Pueden verse las monografías de F. Delgado Piqueras, La terminación convencional del procedimiento administrativo, 1995; A. Huergo Lora, Los contratos sobre los actos y las potestades administrativas, 1998; y La resolución extrajudicial de conflictos en el Derecho administrativo, 2000; A. de Palma Teso, Los acuerdos procedimentales en el Derecho Administrativo, 2000; R.O. Bustillo Bolado, Convenios y Contratos Administrativos: Transacción, Arbitraje y Terminación Convencional del Procedimiento, 2004; y M. Sánchez Morón, Á. Sánchez Blanco y J. M. Trayter Jiménez, La apertura del procedimiento administrativo a la negociación de los ciudadanos en la Ley 30/1992, de Régimen Jurídico del as Administraciones Públicas y del Procedimiento Administrativo Común, 1995. Aunque el art. 86 LPAC se refiere a los convenios, debe notarse que los previstos en este artículo no se rigen por la nueva regulación general que establece el Capítulo VI del Título I de la LRJSP como expresamente indica el artículo 48. 9 LRJSP. Vid.
} 
nistrativos. Respecto de éstos debe estarse a lo previsto en el artículo 112. 2 LPAC que (en los mismos términos que el artículo 107. 2 Ley 30/1992), prevé la sustitución de los recursos administrativos ordinarios por otros procedimientos de impugnación, que es la que nos interesa para, sobre su base, analizar las previsiones en la legislación deportiva general y andaluza en particular.

\section{LA SUSTITUCIÓN DE LOS REGURSOS ADMINISTRATIVOS ORDINARIOS POR OTROS MEGANISMOS}

\section{Planteamiento}

Ha sido tradicional clasificar los recursos administrativos en tres categorías: los recursos ordinarios, que son los que caben frente a cualquier acto administrativo y por cualquier infracción del ordenamiento jurídico; los recursos extraordinarios, que son los que sólo se admiten por concretos motivos, aunque respecto de cualquier acto; y los recursos especiales que son los que permiten alegar cualquier vicio pero sólo respecto de determinados actos administrativos. Las dos primeras clases se han regulado en la legislación general de procedimiento administrativo mientras que los recursos especiales en las leyes sectoriales, que son las que concretan qué actos son los recurribles. Así sucede también en la vigente LPAC que, como la Ley 30/1992, regula los recursos administrativos ordinarios de alzada y potestativo de reposición y el recurso extraordinario de revisión, y establece las pautas para el establecimiento de recursos especiales en el artículo 112. 2 en los términos que seguidamente veremos. No obstante, estos recursos no son en absoluto nuevos y nuestro ordenamiento jurídico los contempla mucho antes de la aprobación de la Ley 30/1992, aunque han recuperado actualidad en los últimos tiempos ${ }^{9}$. Tienen tal carácter las reclamaciones económico-administrativas, que existen desde hace más de un siglo y hoy se recogen en el apartado 4 del artículo 112 LPAC; o la impugnación ante órganos colegiados en los procesos de selección del profesorado universitario como las comisiones de reclamación del art. 43 de la Ley Orgánica 11/1983, de 25 de agosto, de reforma universitaria, o las previstas en el art. 66 de la vigente Ley Orgánica 6/2001, de 21 de diciembre, de Universidades. De los creados recientemente destaca el recurso especial en materia de contratación que, en la Administración General del Estado, se resuelve por Tribunal Administrati-

L. Alarcón Sotomayor, «El procedimiento administrativo», en Derecho administrativo. II Régimen jurídico básico y control de la Administración, 2016, pág.57-59; R. O. Bustillo Bolado, «Los convenios», en Tratado de Procedimiento Administrativo Común y Régimen Furídico Básico del Sector Público, 2017, I, pág. 1063-1065 así como, en el Tomo II de esta última obra colectiva, F. Hernando González, «La terminación del procedimiento», pág. 1740 y ss.

$9 \quad$ Sobre el reconocimiento reciente de estos recursos especiales y procedimientos alternativos en la LPAG puede verse V. Escuin Palop, «Régimen general de los recursos administrativos», en Tratado..., cit, II, pág. 2402 ss. 
vo Central de Recursos Contractuales (artículos 40 y 41 del Real Decreto Legislativo 3/2011, de 14 de noviembre, por el que se aprueba el texto refundido de la Ley de Contratos del Sector Público); o la reclamación en materia de acceso a la información pública ante el Consejo de Transparencia y Buen Gobierno (artículos 23 y 24 de la Ley 19/2013, de 9 de diciembre, de transparencia, acceso a la información pública y buen gobierno $)^{10}$. También tiene esta naturaleza el recurso especial en materia de dopaje ante el Tribunal Administrativo del Deporte y el que procede contra los actos federativos en materia de disciplina deportiva que desde hace tiempo se ha atribuido a órganos colegiados de especialistas, pues la legislación deportiva se adelantó a una posibilidad que hasta 1992 no se incorporó a la legislación general de procedimiento administrativo.

En efecto, la Ley 13/1980, de 31 de marzo, General de la Cultura Física y del Deporte, creó el Comité Superior de Disciplina Deportiva como un órgano colegiado que resolvía en última instancia administrativa las cuestiones disciplinarias, y sus resoluciones serían susceptibles de recurso contencioso-administrativo, línea que se ha mantenido en la legislación posterior estatal y autonómica. También la reciente Ley 5/2016, de 19 de julio, del deporte de la Comunidad Autónoma de Andalucía ha creado el Tribunal Administrativo del Deporte de Andalucía que, según proclama la exposición de motivos, asume la resolución de los litigios deportivos permitiendo «de cara a los distintos agentes del deporte y a la ciudadanía en general, tener como referente claro y único un órgano a quien dirigirse para resolver los conflictos que se susciten de carácter sancionador, disciplinario, de resolución de recursos en el ejercicio de funciones públicas de carácter administrativo, de control de legalidad de los procesos electorales federativos, así como para la conciliación de conflictos deportivos mediante la vía arbitral o la mediación». Este artículo se centra en el estudio de este Tribunal y sus diferentes competencias que inciden en el permanente debate sobre la extensión del Derecho Administrativo en lo deportivo, que se agudiza con la nueva Ley andaluza que avanzaría en esa «administrativización» como se comprobará11 . Para ello, segui-

10 Los estudios sobre estos recursos o reclamaciones especiales son numerosos y, en lo que ahora nos interesa, ponen de manifiesto su eficacia en la resolución de conflictos, eludiendo el proceso contenciosoadministrativo. Según el Informe sobre la fusticia Administrativa 2016, sólo un 12\% de las resoluciones del Tribunal Económico-administrativo Central son recurridas ante la jurisdicción contencioso-administrativa, porcentaje que desciende al 7\% respecto de las resoluciones de los órganos de los recursos contractuales lo que avala este planteamiento a pesar de las dificultades en el manejo de los datos (págs. 35 y 143).

11 En lo esencial es una consecuencia más de la compleja naturaleza de las federaciones deportivas que se definen legalmente como privadas pero presentan caracteres propios de las corporaciones como es la necesaria pertenencia a las mismas para participar en competiciones deportivas oficiales. Si lo primero determina la naturaleza privada de su organización interna lo segundo justificaría los poderes de fiscalización y tutela que ejercen las Administraciones públicas. Vid. A. Camps Povill, Las federaciones deportivas: régimen jurídico, 1996. Existe una amplia bibliografía sobre esta polémica y sus diferentes manifestaciones entre las que destacan las siguientes monografias, G. Real Ferrer, Derecho público del deporte, 1991; J. Bermejo Vera, 
damente se analiza con carácter general la sustitución de los recursos administrativos ordinarios por otras vías de resolución de conflictos, para centrarnos en las previsiones al respecto de la legislación deportiva, primero, la estatal, y después, la andaluza.

\section{Los criterios del artículo 112. 2 LPAC.}

La Ley 30/1992 generalizó la posibilidad de sustituir el recurso de alzada por «sistemas de solución de reclamaciones y recursos distintos a los tradicionales y cuya implantación se va haciendo frecuente en los países de nuestro entorno y que ya existen, en algún caso, en nuestro propio ordenamiento» según reconocía la exposición de motivos. Con la reforma de 1999, se profundiza en esta línea, incluyendo al recuperado recurso potestativo de reposición, por un lado; y extendiendo la sustitución a las Administraciones locales dentro del respeto a las funciones resolutorias de los electos locales, por otro lado ${ }^{12}$. Esta regulación ha sido incorporada sin modificaciones a la vigente LPAC que, en su art. 112. 2, establece $^{13}$ :

«Las leyes podrán sustituir el recurso de alzada, en supuestos o ámbitos sectoriales determinados, y cuando la especificidad de la materia así lo justifique, por otros procedimientos de impugnación, reclamación, conciliación, mediación y arbitraje, ante órganos colegiados o comisiones específicas no sometidas a instrucciones jerárquicas, con respeto a los principios, garantías y plazos que la presente Ley reconoce a las personas y a los interesados en todo procedimiento administrativo.

En las mismas condiciones, el recurso de reposición podrá ser sustituido por los procedimientos a que se refiere el párrafo anterior, respetando su carácter potestativo para el interesado.

La aplicación de estos procedimientos en el ámbito de la Administración Local no podrá suponer el desconocimiento de las facultades resolutorias reconocidas a los órganos representativos electos establecidos por la Ley».

Corresponde a las Leyes llevar a cabo la sustitución de los recursos administrativos ordinarios, la alzada y la reposición potestativa, en supuestos o ámbitos

Constitución y Deporte, 1998; I. Agirreazkuenaga Zigorraga, Intervención pública en el deporte, 1998; M. LoraTamayo Vallvé, El derecho deportivo: entre el servicio público y el mercado, 2003; J. C. Tejedor Bielsa, Público y privado en el deporte, 2003; A. Palomar Olmeda El sistema deportivo español: una visión diferente y pautas de reforma, 2011; y E. de la Iglesia Prados, Derecho privado y deporte: relaciones jurídico personales, 2014.

${ }_{12}$ La Ley 4/1999 quería potenciar estas vías y así lo reflejaba su Disposición adicional segunda, que establecía el deber del Gobierno de remitir en el plazo de dieciocho meses un proyecto de ley a las Cortes Generales regulando los procedimientos de impugnación, reclamación, conciliación, mediación y arbitraje sustitutivos de los recursos de alzada y reposición, aunque nunca tuvo lugar.

13 En los mismos términos el artículo 115 de la Ley 9/2007, de 22 octubre, de Administración de la Junta de Andalucía. 
sectoriales determinados y cuando la especificidad de la materia lo justifique. Por tanto, en principio, no se admitiría que una ley autonómica sustituyera de manera generalizada y global los recursos de alzada y reposición por otro mecanismo de impugnación, pero será suficiente una mínima argumentación sobre los supuestos o ámbitos sectoriales y la especificidad de la materia en los que resulta conveniente la sustitución para cubrir esta exigencia ${ }^{14}$. Como se trata de sustituir a los recursos administrativos ordinarios, permitirán combatir una resolución administrativa que pone fin a un procedimiento administrativo en vía de decisión (sea la resolución en sentido estricto o la relativa a las otras formas de terminación) o los actos de trámite que deciden directa o indirectamente el fondo del asunto, determinan la imposibilidad de continuar el procedimiento, producen indefensión o perjuicio irreparable a derechos e intereses legítimos según dispone el artículo 112. 1 LPAC. También procederá contra los actos presuntos y contra las desestimaciones presuntas, pero no contra los reglamentos.

Mayores dudas interpretativas suscita la referencia del precepto a «otros procedimientos de impugnación, reclamación, conciliación, mediación y arbitraje, ante órganos colegiados o comisiones específicas no sometidas a instrucciones jerárquicas». Los procedimientos de impugnación o reclamación no podrán ser muy diferentes de los que se tramitan con la interposición de los recursos de alzada o reposición pues lo relevante es que su resolución no corresponde al superior jerárquico o al que ha dictado el acto, sino a un órgano colegiado ajeno a la jerarquía. Pero no parece sencillo integrar con la pretendida sustitución de los recursos ordinarios la conciliación, la mediación o el arbitraje $\mathrm{e}^{15}$. Los tres procedimientos tienen en común

14 Así, por ejemplo, lo hacía el borrador de un proyecto de creación del Tribunal Administrativo de la Junta de Andalucía de 2009 del que da cuenta M. J. Sarmiento Acosta, «Fórmulas complementarias de resolución de controversias jurídico-administrativas: acerca de la creación de comisiones o tribunales administrativos», en $R A A P \mathrm{n}^{\circ}$. 76, 2010, pág. 106, que conocería de los recursos contra actos dictados por la Administración andaluza y sus agencias en las materias con un alto volumen de recursos en sede judicial y con asuntos de menor cuantía o de carácter repetitivo.

15 Señala L. Miguez Macho («Autotutela administrativa y tutela judicial efectiva: nuevas perspectivas para el proceso contencioso-administrativo», en $R G D A \mathrm{n}^{\circ} 38,2015$, pág. 24) que, en los procedimientos alternativos de resolución de conflictos, se suelen distinguir entre los de heterocomposición de intereses y de autocomposición de intereses: «los primeros se caracterizan por la intervención de un tercero, libremente aceptado por las partes, que resuelve la controversia en Derecho o en equidad; su modelo es el arbitraje. En los segundos, en cambio, son las propias partes las que llegan a la solución del conflicto, bien sin intervención de un tercero, como sucede en supuestos de transacción, bien con participación de un tercero, como sería el caso de la conciliación y la mediación». La transacción se diferenciaría de la conciliación y la mediación en que en la primera se producen cesiones mutuas con renuncia de derechos, mientras que en esta última más bien se busca una solución compartida por las partes sin necesidad de que renuncien a sus derechos. Por otra parte, conciliación y mediación se distinguen por el papel que desempeña el tercero al que acuden las partes: sin imponer nunca una solución (que sería lo característico del arbitraje), en el primer caso se limita a facilitar el acuerdo, mientras que en el segundo tiene facultades para proponérselo a las partes. 
la intervención (aunque con diferente alcance) de un tercero y no me parece que un órgano administrativo colegiado pueda tener tal carácter, aunque no esté sujeto a instrucciones jerárquicas. Coincido con el Profesor Tornos Mas, que ha manifestado sus dudas sobre la utilidad de estos otros mecanismos como sustitutivos de los recursos administrativos; podrían ser aceptados, en su caso, en la fase de decisión, para evitar que se produzca el enfrentamiento en aquellas materias en las que existe un margen de disponibilidad, pero no son instrumentos útiles para resolver conflictos constituidos, cuando la Administración ya ha adoptado el acto ${ }^{16}$. Varias son las razones que explican esta desconfianza: desde los principios generales de legalidad y competencia hasta la presunción de validez de los actos administrativos y su ejecutividad y ejecutoriedad, pasando por la expresa prohibición de transigir judicial o extrajudicialmente sobre los bienes y derechos del Patrimonio del Estado o de la Hacienda Pública, o de someter los mismos a arbitraje salvo mediante acuerdo del Consejo de Ministros previa audiencia del Consejo de Estado (arts. 31 de la Ley de Patrimonio de las Administraciones Públicas y 7 de la Ley General Presupuestaria $)^{17}$. Quizá por estas razones los supuestos en los que el ordenamiento jurídico administrativo admite estos procedimientos lo hace para intentar solucionar el conflicto antes de que se produzca y, por tanto, no en sustitución de los recursos administrativos ordinarios ${ }^{18}$. Pero también encontramos ejemplos en la legislación deportiva de la llamada «revisión administrativa bajo formula arbitral» que se pretende sustitutiva de los recursos administrativos con el alcance del artículo 112. 2 LPAC. Así, en la anterior Ley Orgánica de lucha contra el dopaje, la Ley Orgánica 7/2006, de 21 de noviembre, que no llegó a funcionar y se reemplazaría por el recurso es-

16 «Los medios complementarios a la resolución jurisdiccional de los conflictos administrativos», en $R A P \mathrm{n}^{\circ}$. 136, 1995, pág. 169-177 y, más reciente, «Los órganos administrativos independientes de resolución de recursos administrativos. La proportionate dispute resoluction» en Las vías..., cit., págs.804-806. Recordemos, no obstante, que el profesor Tornos ha sido uno de los principales defensores de los órganos administrativos especializados para resolver los conflictos como puede comprobarse en «El Consell Tributari del Ayuntamiento de Barcelona», en $D A$ n $^{\circ} .220$, 1989, págs. 207 y ss.

17 Sobre las dificultades que la mediación suscita cuando se trata de ejercer potestades administrativas, puede verse J. M. Chozas Lozano, «El ámbito de la mediación, como mecanismo de autocomposición de las partes en la resolución de conflictos, en la Universidad complutense de Madrid», en REDA nE 170, 2015, pág. 337 ss.

18 Por ejemplo, el artículo 50 del Texto Refundido de la Ley de Contratos del Sector Público admite que los entes del sector público que no sean Administraciones públicas puedan remitir a un arbitraje sujeto a la Ley 60/2003, de 23 de diciembre, de Arbitraje, para la solución de las diferencias que puedan surgir sobre los efectos, cumplimiento y extinción de los contratos que celebren; o el artículo 45 del Real Decreto Legislativo 5/2015, de 30 de octubre, por el que se aprueba el texto refundido de la Ley del Estatuto Básico del Empleado, que prevé que las Administraciones públicas y las organizaciones sindicales acuerden la creación, configuración y desarrollo de sistemas de solución extrajudicial de conflictos colectivos. 
pecial ante el Tribunal Administrativo del Deporte que veremos ${ }^{19}$; o en la vigente Ley 1/2015, de 23 de marzo, del ejercicio físico y deporte de La Rioja ${ }^{20}$. Pero bajo

19 El artículo 29 de la Ley Orgánica 7/2006 regulaba la revisión administrativa bajo fórmula arbitral de las resoluciones en materia de dopaje dictadas por las Federaciones deportivas o por la Comisión de Control y Seguimiento de la Salud y el Dopaje, que correspondía a una sección específica del Comité Español de Disciplina Deportiva. La sección estaría integrada por un miembro del Comité que actuaría como presidente y por otros dos designados, uno por el interesado y otro por acuerdo ente el miembro/ presidente y el interesado, de un listado elaborado por el Consejo Superior de Deportes (art. 18 del Decreto $63 / 2008$, de 25 de enero, por el que se regula el procedimiento para la imposición y revisión de sanciones disciplinarias en materia de dopaje). Si no se alcanzaba un acuerdo, el tercer miembro sería el Presidente del Comité. Si la revisión se solicitaba por la Comisión de Seguimiento o por la Agencia Estatal Antidopaje, los dos vocales se designan por el presunto infractor y por quién ha solicitado la revisión. La revisión tenía por objeto determinar si la resolución dictada por los órganos disciplinarios era conforme a derecho, procedía otra sanción o incluso el sobreseimiento. Esté régimen era expresamente declarado como sustitutivo de los recursos administrativos de acuerdo con el artículo 107. 2 de la Ley 30/1992 y su resolución agotaba la vía administrativa, siendo recurrible ante la jurisdicción contencioso-administrativa. Al respecto puede verse, entre otros, L. Parejo Alfonso, «La revisión administrativa de las sanciones por actos en materia de dopaje», en Comentarios a la Ley antidopaje en el deporte, 2007, págs. 273-306; A. Palomar Olmeda, «El Tribunal Administrativo del Deporte», en Cuestiones actuales de derecho del deporte, 2015, págs. 84-87; G. Real Ferrer, «Aproximación a los nuevos procedimientos para la imposición y revisión de sanciones por dopaje», en $E l$ nuevo Derecho deportivo disciplinario, 2009, págs. 53-63; J. Rosa Moreno, «Definitiva articulación de la fórmula arbitral en el procedimiento sancionador en materia de dopaje», en Revista Aranzadi de Derecho de Deporte y Entretenimiento, $\mathrm{n}^{\circ} .23,2008$, págs. 225-236; y E. Gamero García, «¿Un sistema arbitral para el dopaje? Consideraciones y alternativas», en Revista Española de Derecho Deportivo, nº. 15, 2005, págs. 61-80 y «La revisión de las sanciones por dopaje» en Comentarios a la Ley Orgánica de Protección de la Salud y de la Lucha contra el Dopaje en el Deporte, 2007, págs. 291-310.

20 La Ley realiza en sus artículos 176 a 187 una detenida regulación de este sistema, detallando tanto las cuestiones organizativas y de funcionamiento como procedimentales, suscitando diversas cuestiones de interés que no podemos analizar ahora. En lo esencial, procede la revisión bajo formula arbitral ante el Tribunal del Deporte de las resoluciones dictadas en el ámbito disciplinario por los órganos competentes de las entidades deportivas de La Rioja, o por los organizadores del ámbito no federado, y de las decisiones adoptadas por los órganos y personas competentes en el ámbito organizativo-competicional y electoral (arts. 178 y 180). El Tribunal es un órgano administrativo colegiado que actuará mediante cortes arbitrales formadas por uno o tres árbitros designados por el Tribunal de entre los abogados en ejercicio incluidos previamente en un listado elaborado por el propio Tribunal (arts. 176, 181 y 182). La parte que desee someter en vía de recurso al Tribunal del Deporte de La Rioja un acuerdo o decisión formulará el escrito de impugnación y el Secretario del Tribunal acordará la admisión a trámite designando, mediante diligencia de ordenación, al árbitro o árbitros de entre los que formen parte de la lista, atendiendo a riguroso turno de reparto, notificando a estos y a las partes el nombre de los designados a efectos de su abstención o recusación en el plazo de tres días. Transcurrido este plazo, el secretario reclamará el expediente al órgano que dictó el acto recurrido, dándole traslado además del escrito de impugnación para que, en el plazo máximo de quince días, remita el expediente y formule escrito de oposición conteniendo los hechos y fundamentos que sustenten el acto impugnado. Se pondrán a disposición del árbitro/s la totalidad de las actuaciones para que decida sobre la práctica de pruebas. Finalizado el plazo para la práctica de la prueba, quedará el expediente para la deliberación o debate de la Corte Arbitral, que deberá dictar resolución expresando los hechos imputados, los preceptos infringidos y los que habilitan la sanción que se imponga cuando el expediente corresponda al ámbito disciplinario o, en su caso, los hechos probados, la fundamentación jurídica concordante y la consecuencia procedente en derecho cuando los expedientes correspondan a los 
ningún concepto se trata de resolver el conflicto en vía de recurso mediante arbitraje, salvo que recurramos a un concepto de arbitraje sumamente forzado, pues ni se elude el proceso judicial ni cabe entender con propiedad que resuelve un tercero ${ }^{21}$. Me parece claro que no cabe entender que resuelve un tercero porque el interesado designe a un miembro de un órgano colegiado o se articule la participación en el procedimiento de abogados en ejercicio, en ambos casos partiendo de un listado previo elaborado por la Administración. Además, en ambos supuestos, la resolución corresponde al órgano administrativo colegiado, que debe resolver dentro de plazo (si no lo hace se producirá el silencio administratico negativo) y es recurrible ante la jurisdicción contencioso-administrativa ${ }^{22}$.

La atribución de la competencia para resolver la reclamación o impugnación a un órgano colegiado no sometido a instrucciones jerárquicas, en lugar de al mismo órgano que dictó el acto o a su superior, constituye el elemento esencial de la sustitu-

ámbitos organizativo o electoral. Las resoluciones, acuerdos o laudos dictados por las cortes arbitrales en el ejercicio de las funciones establecidas en esta Ley se entenderán del Tribunal del Deporte de La Rioja (art. 183), adoptarán la forma de resolución, agotan la vía administrativa y contra las mismas únicamente podrá interponerse recurso contencioso-administrativo (art. 180). Además de esta revisión bajo formula arbitral, la Ley riojana también atribuye al Tribunal del Deporte el arbitraje para resolver controversias jurídico deportivas entre entidades deportivas y terceros, si lo aceptan expresamente las partes y, en tal caso, la decisión tendrá forma de laudo y frente al mismo no se podrá acudir a ningún orden jurisdiccional (arts. 178 y 184).

21 Así lo entiende también A. Huergo Lora (La resolucion extrajudicial..., cit., pág. 164): «nada tiene que ver con el arbitraje los intentos o propuestas de encomendar la resolución de ciertos litigios administrativos a comisiones más o menos especializadas, dotadas de cierta independencia, pero cuya organización y composición se establecen por normas jurídicas y no por la voluntad de las partes del litigio». V. Escartín Escudé, «El arbitraje...», cit. , págs. 144-145 sostiene que esta revisión bajo formula arbitral tiene «naturaleza arbitral que, evidentemente, coincide con la del arbitraje administrativo que regula el artículo 107.2 LPAC (es decir, con su caracterización como mecanismo de impugnación sustitutivo del recurso administrativo clásico) y no con la derivada del concepto tradicional de arbitraje de Derecho privado, que presenta a la Ley de Arbitraje de 2003 como sustento normativo principal». Sobre el arbitraje y el Derecho Administrativo, pueden verse las monografias de J. Rosa Moreno, El arbitraje administrativo, 1998; y de M. García Pérez, Arbitraje y derecho administrativo, 2011.

22 La Disposición adicional vigésima novena, apartado 4, de la Ley 14/2000, de 29 de diciembre, de Medidas fiscales, administrativas y del orden social establece que «la terminación convencional de procedimientos administrativos, así como los procedimientos de mediación, arbitraje o conciliación, no están sujetos al régimen de silencio administrativo previsto en la Ley 30/1992, de Régimen Jurídico de las Administraciones Públicas y del Procedimiento Administrativo Común». Debe entenderse que esta regla es de aplicación cuando efectivamente se trate de procedimientos de mediación, arbitraje o conciliación, y no a estos mecanismos denominados de «revisión bajo formula arbitral», en los que la competencia para resolver se atribuye a un órgano administrativo. Así lo entiende también la Ley del Deporte de la Rioja que, en su artículo. 185.3, establece que «transcurridos los términos indicados y aunque persista la obligación de dictar resolución expresa, se podrá entender que la impugnación ha sido desestimada, quedando expedita la vía contencioso-administrativa cuando proceda». 
ción de los recursos ordinarios y la consecución de los fines perseguidos ${ }^{23}$ : que se dicte una resolución conforme a derecho que contribuya a satisfacer las pretensiones de los recurrentes eludiendo el ulterior recurso contencioso-administrativo ${ }^{24}$. También podría atribuirse la resolución a un órgano unipersonal especializado ajeno a la estructura jerárquica de la Administración siempre que se garantizara su capacidad para decidir sin subordinación jerárquica ${ }^{25}$. No lo ha entendido así el legislador estatal, que vincula la independencia en la adopción de la decisión con la colegialidad, aunque no constituye una garantía en si misma de la autonomía funcional: dependerá de la composición del propio colegio y del estatuto jurídico de sus miembros. En principio, los órganos colegiados no están sujetos a instrucciones jerárquicas, pues forman su voluntad siguiendo el procedimiento colegial, pero si todos los miembros están condicionados a título individual puede quedar predeterminada la decisión colegiada por un superior jerárquico común ${ }^{26}$. Por eso, deben ser órganos de expertos no condicionados

23 Hace ya tiempo que M. Sánchez Morón, El control de las Administraciones públicas y sus problemas, 1991, pág. 148, propuso «modificar el modelo de recurso administrativo, atribuyendo su resolución -salvo cuando se recurran decisiones normativas o de contenido general o político evidente- a órganos especializados de control no sometidos a instrucciones». También, entre otros, M. J. Sarmiento Acosta, Los recursos administrativos en el marco de la justicia administrativa, 1996, en particular págs. 313-314 y $419-424$ y, más recientemente, en «Fórmulas...», cit., pág. 80 ss.

24 Como he puesto de manifiesto en otro lugar («La resolución de conflictos por vías distintas de los recursos administrativos ordinarios: los ejemplos del deporte y la unidad de mercado» en La mediación como alternativa a la judicialización de asuntos civiles, mercantiles y administrativos, 2017, págs. 305-306) aligerar los asuntos que llegan a los tribunales es un motivo sin duda relevante para articular estas vías alternativas pero no es menos importante, aunque no siempre se señala así, la adecuada satisfacción de los derechos de los ciudadanos en sus relaciones con las Administraciones públicas y que las garantías que la legislación les reconoce no sean simples declaraciones formales como sucede con frecuencia ante actos administrativos de clara ilegalidad. No son pocas las ocasiones en las que los interesados interponen los recursos ordinarios ante actuaciones manifiestamente contrarias a la legislación que se desestiman por silencio pero que no compensa en tiempo, dinero, o esfuerzo acudir a los tribunales, con la frustración que conlleva y la vulneración de hecho del Estado de Derecho.

25 También un órgano unipersonal puede calificarse como de experto y actuar con autonomía funcional si cuenta con un estatuto jurídico que lo garantice. Por ejemplo, ciertas decisiones de los Tribunales Económico-Administrativos se adoptan por sus miembros individualmente (art. 231 de la Ley General Tribuntaria); el órgano encargado de la resolución del recurso especial de contratación o de la reclamación en materia de transparencia puede ser unipersonal; también el Director de la Oficina de Conflictos de Intereses que regula la Ley 3/2015, de 30 de marzo, del ejercicio del alto cargo de la Administración General del Estado, que se nombra por el Consejo de Ministros, «previa comparecencia de la persona propuesta para el cargo ante la Comisión correspondiente del Congreso de los Diputados, con el fin de que examine si su experiencia, formación y capacidad son adecuadas para el cargo».

26 En principio la creación de un órgano colegiado excluye la subordinación jerárquica pues la formación de la voluntad colegiada será el resultado de la integración de las voluntades individuales de sus miembros, sin condicionamientos previos por razones de jerarquía incluso en órganos burocráticos. Ese es el fundamento de la colegialidad. Si todos los miembros del órgano dependen de un mismo superior jerárquico y éste dicta las órdenes oportunas, queda predeterminado el acto colegial y, en tal hipótesis, la creación del órgano colegiado responde a motivaciones diferentes de las que deben caracterizar la adopción colegiada 
por una relación de subordinación jerárquica ni dependientes a título individual de la organización a la que se quiere controlar como sucede, sin duda, si los miembros son especialistas, funcionarios o no, ajenos a la Administración autora de los actos controlados. Y este debe ser el principal objetivo del establecimiento de una vía alternativa para resolver las impugnaciones: atribuir la resolución (o un informe preceptivo) del recurso a un órgano colegiado, no muy numeroso y de expertos, que resuelva conforme a derecho, aplicando la legalidad vigente sin condicionamientos externos ${ }^{27}$.

\section{EL TRIBUNAL ADMINISTRATIVO DEL DEPORTE ESTATAL COMO EJEMPLO DE SUSTITUGIÓN DE LOS REGURSOS AD- MINISTRATIVOS ORDINARIOS}

Tradicionalmente, la resolución de los recursos en materia de disciplina deportiva ha correspondido a órganos administrativos de naturaleza colegiada adscritos orgánicamente al Consejo Superior de Deportes (en adelante, CSD), si bien actuaban con independencia de éste y de las Federaciones deportivas. Así lo establecía, primero, el art. 34 de la Ley 13/1980, de 31 de marzo, General de la Cultura Física y del Deporte, respecto del Comité Superior de Disciplina Deportiva; y, después, el art. 84 de la Ley 10/1990, de 15 de octubre, del Deporte, en relación con el Comité Español de Disciplina Deportiva. Con posterioridad, la disposición final cuarta de la Ley Orgánica 3/2013, de 20 de junio, de protección de la salud del deportista y lucha contra el dopaje en la actividad deportiva, crea el Tribunal Administrativo del Deporte (en adelante, TAD), modificando al efecto el artículo 84 de la Ley del Deporte ${ }^{28}$. Mediante el Real Decreto 53/2014, de 31 de enero, se desarrolla su composición,

de una decisión. Así he tenido ocasión de ponerlo de relieve en distintas ocasiones desde mi monografía Los órganos colegiados, 1999, págs. 64-66, y recientemente en «Regulación de los órganos colegiados» en Innovaciones en el procedimiento administrativo común y el régimen jurídico del sector público, 2016, pág. 240. También J. Valero Torrijos, Los órganos colegiados: análisis histórico de la colegialidad en la organización pública española y régimen jurídico-administrativo vigente, 2002.

27 En esta línea el Informe explicativo y propuesta de anteproyecto de ley de eficiencia de la Furisdicción Contencioso-Administrativa, Ministerio de Justicia, Marzo de 2013 (disponible enhttp://www.mjusticia.gob. es/cs/Satellite/Portal/es/actividad-legislativa/comisiongeneral-codificacion/propuestas) propone, no sustituir los recurso ordinarios, sino los órganos competentes para resolverlos por órganos colegiados independientes, solo sujetos a la legalidad.

${ }_{28} \mathrm{Al}$ respecto puede verse A. Palomar Olmeda, «El Tribunal...», cit, pág. 75 ss; E. Carbonell Porras, «La resolución...», cit., pág. 293 ss; E. Arnaldo Alcubilla, «La naturaleza y las funciones del Tribunal Administrativo del Deporte», en Los retos del deporte profesional y profesionalizado en la sociedad actual, 2017 pág. 93 ss; y J. J. Seoane Osa, «El Tribunal Administrativo del Deporte (TAD) y el dopaje», en Revista Aranzadi de Derecho de Deporte y Entretenimiento nº. 43, 2014 pág. 357 ss. 
organización y funciones, y su puesta en funcionamiento supuso la desaparición del Comité Español de Disciplina Deportiva y de la Junta de Garantías Electorales ${ }^{29}$.

De esta forma la legislación estatal se suma así a algunas legislaciones autonómicas que han creado órganos administrativos que resuelven recursos a los que denominan «tribunal» ${ }^{30}$. En todo caso, bajo ningún concepto el nombre de tribunal debe inducir a error y, por eso, se califica siempre como administrativo: son órganos administrativos de naturaleza colegiada y, por tanto, nada hay en ellos de poder judicial, sujetándose plena e íntegramente al Derecho administrativo ${ }^{31}$. El identificar a estos órganos colegiados como tribunales en lugar de comisiones o comités persigue

$29 \quad$ El Dictamen del Consejo de Estado 29/2014, de 23 de enero, sobre el proyecto de real decreto por el que se desarrolla la composición, organización y funciones del Tribunal Administrativo del Deporte se refiere a la reducción de costes de esta regulación: «La fusión del Comité Español de Disciplina Deportiva y de la Junta de Garantías Electorales en el TAD supone la reducción de sus miembros, de 17 a 7 . Lo que significa un ahorro de aproximadamente 66.275,40 euros anuales en asistencias, es decir, un 46\% del coste, toda vez que los miembros del TAD mantendrán las condiciones de remuneración que actualmente se aplican a los integrantes del Comité Español de Disciplina Deportiva y de la Junta de Garantías Electorales. Por lo que respecta a las ponencias, la supresión de ambos órganos, supondría un ahorro de 31.173,12 euros anuales, es decir, un 30\% del coste actual. De manera que se puede cuantificar el ahorro total que se deduce del presente proyecto normativo en 97.448,52 euros. A lo anterior se suma el previsible ahorro en indemnizaciones por desplazamiento a los miembros del TAD, como consecuencia de la implantación de las reuniones por medios electrónicos (proyectado artículo 4).» Por eso se afirma que la puesta en funcionamiento del TAD no supondrá incremento del gasto. Sobre la relevancia de este dato y no otros más sustantivos, puede verse la crítica de A. Palomar Olmeda, «El Tribunal...», cit., pág. 94 y 118-119, que, además, pone de relieve que las competencias de la Junta de Garantías Electorales no encajan en la disciplina deportiva que se encomiendan al TAD.

30 Salvo error, la primera Comunidad Autónoma que emplea la denominación de tribunal es Cataluña con la Ley 8/1999, de 30 de julio, de la jurisdicción deportiva, después integrada en el Decreto Legislativo 1/2000, de 31 de julio, por el que se aprueba el Texto único de la Ley del Deporte de Cataluña. La seguirán otras leyes autonómicas como la Ley 2/2003, de 28 de marzo, del deporte de Castilla y León, la Ley 2/2011, de 22 de marzo, de la Comunidad Valenciana o la más reciente Ley 1/2015, de 23 de marzo, de La Rioja. En todo caso, las funciones y el régimen jurídico de estos «tribunales» es equiparable al de los comités de disciplina deportiva en aquellas Comunidades Autónomas que mantienen esta denominación como hasta 2013 sucedía en la legislación estatal y hasta 2016 en la andaluza.

31 El Consejo General del Poder Judicial en su informe de 11 de octubre de 2012 sobre el anteproyecto de Ley Orgánica 3/2013 llamaba la atención sobre este dato en los siguientes términos: «Este Consejo considera que la denominación de "Tribunal" debe reservarse en nuestro ordenamiento exclusivamente para aquellos órganos colegiados que ejerzan una auténtica potestad jurisdiccional, y cuyos integrantes pertenezcan al Poder Judicial (artículos 117.3 y 4 CE). Ello no sucede con el Tribunal Administrativo del Deporte, que es un órgano de naturaleza administrativa adscrito al Consejo Superior de Deportes, por mucho que se establezca que actuará con independencia de éste y que sus miembros gozarán de independencia e inamovilidad, sin que puedan recibir orden o instrucción alguna de ninguna autoridad pública o de otra persona. Se recomienda pues buscar una denominación alternativa, que resultaría igualmente válida y que encajaría mejor con la tradición en esta área, como podría ser "Comité", "Consejo", "Junta", o cualquier otro que impida la equivocidad que genera el vocablo "Tribunal", como término asociado a órganos que ejercen funciones jurisdiccionales». 
destacar que actúan con autonomía funcional como, por otra parte, corresponde a la naturaleza colegiada de la toma de decisiones. Así, por ejemplo, desde siempre la legislación de procedimiento administrativo se ha referido a los «tribunales y jurados de oposiciones y concursos» para hacerlos depender a efectos del recurso de alzada de la autoridad que haya nombrado a su presidente, regla que hoy recoge el artículo 121 LPAC, y que antes establecían los artículos 114 de la Ley 30/1992 y 122 de la Ley de Procedimiento Administrativo de 17 de julio de 1958. Del mismo modo, también el órgano administrativo colegiado que resuelve las reclamaciones económico-administrativas se denomina tribunal y existe desde hace más de un siglo; o más recientemente, también se llaman tribunales los órganos colegiados competentes para resolver el recurso especial en materia de contratación. La finalidad perseguida por el legislador deportivo es reforzar la independencia y autonomía funcional del órgano encargado de resolver los conflictos deportivos, al menos en su apariencia y denominación.

Según el artículo 84 de la Ley del Deporte, corresponden al TAD las siguientes funciones:

«a) Decidir en vía administrativa y en última instancia, las cuestiones disciplinarias deportivas de su competencia, incluidas las señaladas en la Ley Orgánica de Protección de la Salud del Deportista y Lucha contra el Dopaje en la Actividad Deportiva.

b) Tramitar y resolver expedientes disciplinarios a instancia del Consejo Superior de Deportes y de su Comisión Directiva, en los supuestos específicos a que se refiere el artículo 76 de la Ley del Deporte.

c) Velar, de forma inmediata y en última instancia administrativa, por el ajuste a derecho de los procesos electorales en los órganos de gobierno de las Federaciones deportivas españolas.

d) Cualesquiera otras que se le atribuyan en su normativa reguladora».

Como nos interesa la sustitución de los recursos ordinarios con el alcance previsto en el artículo 112 LPAC, prescindimos ahora de la competencia para tramitar y resolver los expedientes disciplinarios contra los presidentes y directivos de las federaciones deportivas y de la de informe en materia electoral ${ }^{32}$. El TAD es el órgano competente para resolver los recursos en tres ámbitos materiales, que son los siguientes:

32 No obstante, interesa destacar, por la diferencia respecto de lo que después veremos en Andalucía, que como señala E. Arnaldo Alcubilla, «La naturaleza...», cit., pág. 109, el TAD nunca puede actuar de oficio contra los directivos federativos. A. Palomar Olmeda, «El Tribunal...», cit., págs. 105-107 tiene en cuenta que se atribuye al Presidente y a la Comisión Directiva del CSD la suspensión cautelar de los presidentes y directivos federativos, y concluye que sería «una competencia conformada sobre la base de la concurrencia y que puede ejercerse por uno u otro órgano». 
En primer lugar, corresponde al TAD la resolución del recurso administrativo especial en materia de dopaje en el deporte regulado en el artículo 40 de la Ley Orgánica 3/2013, que cabe contra las resoluciones y los actos de trámite (que decidan directa o indirectamente el fondo del asunto, determinen la imposibilidad de continuar el procedimiento, causen indefensión o perjuicio irreparable para los derechos e intereses legítimos de los afectados) dictados por la Agencia Española de Protección de la Salud en el Deporte ${ }^{33}$. Este recurso especial podrá interponerse, en todo caso, contra las siguientes resoluciones:

- Las que determinen la comisión de infracciones antidopaje, ya impongan una sanción o resulten absolutorias.

- Las que archiven cualquier procedimiento seguido por infracción de las normas previstas en la presente Ley, bien por motivos formales o bien por causas de fondo, determinando la no continuación del procedimiento.

- Las que declaren el quebrantamiento de una sanción, incluyendo el incumplimiento de la prohibición de participación durante la suspensión.

- Las que fijen la incompetencia del órgano que las dicta.

- Las que impongan una suspensión provisional.

- Las relativas a las autorizaciones de uso terapéutico.

- Las relativas a las suspensiones provisionales de las licencias.

- Las decisiones referentes a la reintegración del periodo de suspensión si no se proporciona la ayuda sustancial que permita descubrir o demostrar una infracción a las normas de antidopaje.

- Las decisiones de la Agencia Española de Protección de la Salud en el Deporte de no reconocer la decisión de otra organización antidopaje.

- Las resoluciones relativas a la suspensión de las sanciones impuestas y al reintegro de los periodos suspendidos en los casos de colaboración en la detección de infracciones a las normas antidopaje.

33 Este artículo 40 ha sido reformado recientemente con la aprobación del Real Decreto-Ley 3/2017, de 17 de febrero, por el que se modifica la Ley Orgánica 3/2013, de 20 de junio, de protección de la salud del deportista y lucha contra el dopaje y se adapta a las modificaciones introducidas en el Código Mundial Antidopaje de 2015. El Real Decreto-Ley ha sido convalidado por el Congreso de los Diputados mediante Acuerdo de 9 de marzo de 2017 (BOE de 18 de marzo de 2017). El Real Decreto-Ley afecta a diversos preceptos que no tienen carácter orgánico de conformidad con la Disposición final segunda de la Ley Orgánica. 
En segundo lugar, el recurso ante el TAD constituye la última instancia en vía administrativa de la disciplina deportiva y, en consecuencia, conoce de las resoluciones sancionadoras que agoten las instancias establecidas por las federaciones deportivas, las ligas profesionales o las agrupaciones de clubes de ámbito estatal (arts. 74 de la Ley del Deporte y 6 del Real Decreto 1591/1992, de 23 de diciembre, sobre disciplina deportiva). También conocerá de las resoluciones disciplinarias que agoten las instancias previstas en las competiciones oficiales escolares y universitarias de ámbito nacional (Disposición adicional primera del Real Decreto 1591/1992).

Y, por último, el TAD resuelve los recursos que se susciten en los procesos electorales en las federaciones deportivas nacionales que se celebran de acuerdo con lo previsto en el artículo 31 de la Ley del Deporte, y en el Real Decreto 1835/1991, de 20 de diciembre, sobre Federaciones deportivas españolas y Registro de Asociaciones Deportivas. El último proceso electoral se ha realizado en 2016, coincidiendo con el año olímpico, conforme a lo previsto en la Orden ECD/2764/2015, de 18 de diciembre, por la que se regulan los procesos electorales en las federaciones deportivas españolas. De acuerdo con los artículos 22 y 23 de la misma, el TAD podrá adoptar las medidas que sean necesarias para garantizar la legalidad de los procesos electorales y conoce en última instancia de los recursos que se interpongan contra:

- El acuerdo de convocatoria de las elecciones, así como contra la distribución del número de miembros de la Asamblea General por especialidades, por estamentos y por circunscripciones electorales, contra el calendario electoral y contra la composición de la Junta Electoral.

- Las resoluciones que adopten las Federaciones deportivas españolas en relación con el censo electoral.

- Las resoluciones de la Junta Electoral respecto de la proclamación de las agrupaciones de candidaturas.

- Las resoluciones adoptadas durante el proceso electoral por las Comisiones Gestoras y las Juntas Electorales de las Federaciones deportivas españolas en relación con el proceso electoral y el resto de cuestiones tratadas en loa Orden.

- Cualesquiera actuaciones, acuerdos y resoluciones adoptados en el ámbito federativo en procedimientos que puedan afectar a la composición de los órganos de gobierno y representación.

Respecto de la naturaleza de estos recursos, el artículo 40 de la Ley Orgánica 3/2013 lo califica como un recurso especial, aunque en el preámbulo se considera como «recurso de alzada impropio». Como es sabido, el recurso de alzada está vinculado con la relación jerárquica entre los órganos administrativos de modo que permite al superior revisar en vía de recurso la decisión adoptada por el inferior. 
Cuando estos dos órganos administrativos no guardan una relación de jerarquía en sentido estricto, como sucede si pertenecen a dos personas jurídicas diferentes, aunque mantengan una relación sumamente dependiente como es la de instrumentalidad, se emplea la expresión «recurso de alzada impropio». Con este calificativo se pone de manifiesto que el órgano de la Administración matriz, al que corresponde resolver ese recurso, ostenta unos poderes de dirección y supervisión de lo actuado por el ente instrumental, equiparables materialmente a los derivados de la relación estricta de jerarquía. Desde esta perspectiva y en un plano estrictamente organizativo, el recurso en materia de dopaje ante el TAD puede considerarse impropio si tenemos en cuenta los diferentes organismos públicos implicados. El TAD es un órgano administrativo adscrito al CSD (organismo autónomo dependiente del Ministerio de Educación, Cultura y Deporte), que controla en vía de recurso los actos dictados por la Agencia Española de Protección de la Salud en el Deporte, que es una agencia estatal adscrita al mismo Ministerio a través del CSD. También puede considerarse como impropio el recurso que procede contra los actos de las Federaciones deportivas española, que, según la legislación vigente, son entidades asociativas privadas, y, por tanto, no dependen ni jerárquica ni instrumentalmente del CSD, aunque sí se encuentren bajo su tutela. Pero realmente no es esto lo relevante pues el TAD tiene garantizada su independencia funcional y no está sujeto ni a la relación de jerarquía en sentido estricto ni a la de instrumentalidad en lo que a la formación de la voluntad colegiada se refiere. Como expresamente reconoce el artículo 15 del Real Decreto $63 / 2008$, de 25 de enero, por el que se regula el procedimiento para la imposición y revisión de sanciones disciplinarias en materia de dopaje, la revisión de las sanciones en materia de dopaje «constituye un procedimiento especial sustitutivo del recurso administrativo, en los términos dispuestos por el artículo 107.2 de la Ley 30/1992», y así lo ha puesto de relieve la doctrina ${ }^{34}$. De esta forma, desde 1980 y ahora con el TAD la legislación deportiva ha sustituido el recurso de alzada impropio, al atribuir la resolución a un órgano colegiado especializado y ajeno al sometimiento jerárquico

$34 \quad$ El encaje del TAD en el artículo 107. 2 de la Ley 30/1992 ha sido puesto de manifiesto por E. Arana García, «Los recursos administrativos en la Unión Europea: hacia un modelo común de justicia administrativa», pág. 77; B. Lozano Cutanda, «Los recursos administrativos en los ordenamientos supranacionales», pág. 140-143; J. $\mathrm{M}^{\mathrm{a}}$ Baño León, «El recurso administrativo como ejemplo de la inercia autoritaria del Derecho público español», pág. 650, todos en Las vías administrativas..., cit. También M. Sánchez Morón, «Nuevas garantías de Derecho Administrativo», en $R A P \mathrm{n}^{\circ} .194,2014$, pág. 279 y 281. No obstante, si tenemos en cuenta la configuración legal de las Federaciones Deportivas como entidades privadas que ejercen por delegación funciones públicas de carácter administrativo, la intervención del TAD en los procesos electorales federativos podría conceptualmente considerarse como una manifestación de la potestad arbitral de la Administración en la resolución de conflictos entre particulares en los que están poresentes intereses públicos. De esta potestad y en general de la actividad arbitral de la Administración se ha ocpado especialmente J.R. Parada Vázquez «Arbitraje y derecho administrativo. La actividad arbitral de la Administración», en REGAP n 23, 1999, págs. 13 ss y, mas recientemente en Derecho administrativo II. Régimen júridico de la actividad administrativa. 2017 
mucho antes de que se incorporara con carácter general a la legislación de procedimiento administrativo.

En efecto, aunque el TAD es un órgano administrativo adscrito orgánicamente al CSD actúa con independencia del mismo según proclama el art. 84 de la Ley del Deporte. Con esta finalidad sus miembros son independientes e inamovibles y, en el ejercicio de sus funciones, no podrán recibir orden o instrucción alguna de ninguna autoridad pública o de otra persona (artículo 1 del Real Decreto 53/2014). Está integrado por siete miembros designados por la Comisión Directiva del CSD, cuatro a propuesta del Presidente y tres de entre los propuestos por las Federaciones deportivas españolas. El nombramiento tiene que recaer sobre personas de nacionalidad española que pertenezcan a los cuerpos docentes universitarios, tengan la categoría de magistrado o fiscal en excedencia, o sean funcionarios en activo de cuerpos o escalas clasificados en el Subgrupo Al para cuyo acceso sea requisito necesario el Título de Licenciado o de Graduado en Derecho. También podrán formar parte del TAD abogados en ejercicio que hayan desempeñado su actividad profesional por tiempo superior a quince años, preferentemente en el ámbito del Derecho Administrativo relacionado directamente con el deporte. El Presidente del TAD se nombra por el Presidente del CSD, a propuesta y de entre los miembros del mismo, y designa al Secretario que asiste a las sesiones con voz pero sin voto, de entre funcionarios de carrera pertenecientes a un cuerpo del subgrupo A1, al servicio de la Administración General del Estado, que sean Licenciados en Derecho o Graduados en Derecho. No podrán ser designados miembros del TAD quienes sean o hayan sido, durante los dos años anteriores a su nombramiento, miembros de los órganos de gobierno, de representación o complementarios de las Federaciones deportivas españolas, Ligas profesionales o clubes deportivos; quienes hayan asesorado directa o indirectamente a éstas durante el mismo periodo, o quienes hayan prestado servicios profesionales a deportistas y cualesquiera otras personas físicas que participen en competiciones o actividades deportivas de carácter oficial. De esta forma se pretende reforzar la objetividad al determinar con carácter general la composición del órgano que es previa y plenamente compatible con la necesaria abstención de alguno de sus miembros respecto de concretos asuntos si concurre una causa de abstención de acuerdo con el artículo 23 LRJSP. El mandato tiene una duración de seis años, renovándose parcialmente cada tres, y no pueden ser cesados libremente por el CSD sino después de la tramitación de un expediente contradictorio si se ha producido un incumplimiento grave de sus obligaciones, incluidas las infracciones graves a la legislación deportiva; una condena a pena privativa de libertad o de inhabilitación absoluta o especial para empleo o cargo público por razón de delito; la incapacidad sobrevenida para el ejercicio de su función o por incurrir en alguna de las causas que impiden el ejercicio de funciones públicas o en alguna de las causas de inelegibilidad o incompatibilidad como miembro del propio TAD. 
Se trata, por tanto, de un órgano colegiado de expertos no subordinado jerárquicamente como exige el artículo 112. 2 LPAC que resuelve los recursos administrativos que procedan contra los actos de las federaciones deportivas en materia electoral y de disciplina deportiva, y contra las resoluciones de la Agencia Española de Protección de la Salud en el Deporte. La excepción significativa (además del informe de los reglamentos electorales federativos) es la atribución al TAD de la competencia para incoar, instruir y resolver, a instancias del CSD, los expedientes disciplinarios contra los Presidentes y directivos de las Federaciones que no casa con la naturaleza del órgano, perturba su funcionamiento y su régimen jurídico, pues debería conocer de estos asuntos en vía de recurso. Sobre este tema volveremos con posterioridad respecto de lo previsto para el órgano equivalente en Andalucía.

El procedimiento de tramitación y resolución por el TAD de todos los expedientes disciplinarios y los relativos a los procesos electorales se rige por la legislación específica, aplicándose supletoriamente la legislación general de procedimiento administrativo (arts. 84 de la Ley del Deporte y 8 del Real Decreto 53/2014). Por tanto, en la actualidad y en ausencia de previsión específica, deberá estarse a lo previsto en la LPAC y en la LRJSP, que establece el régimen jurídico básico de los órganos colegiados y las reglas aplicables a los estatales. En todo caso, la principal particularidad es general de la legislación deportiva, en particular el reconocimiento del carácter inmediatamente ejecutivo de las sanciones sin que la interposición de una reclamación o recurso paralice o suspenda su ejecución (art. 81 de la Ley del Deporte y 40 Ley Orgánica 3/2013). Además y en concreto en relación con el procedimiento en vía de recurso las principales especialidades de los que instruye el TAD respecto de las reglas generales previstas para el recurso de alzada en la LPAC se centran en los plazos para recurrir y resolver que, recordemos ahora, son de un mes para interponer el recurso y de tres meses para resolverlo expresamente (art. 122 LPAC). En los procesos electorales se fija un plazo general para interponer el recurso de dos días hábiles (aunque existen otros plazos para recurrir concretos actos del proceso electoral) y el TAD dispone de un plazo máximo de siete días hábiles para resolverlo; en los procedimientos disciplinarios generales, el plazo para recurrir es de quince días hábiles y respecto del silencio se aplican los de la legislación de procedimiento común (arts. 52 y 57 del Real Decreto 1591/1992). Por último, y de acuerdo con el recién modificado art. 40 de la Ley Orgánica 3/2013, en materia de dopaje, el plazo para recurrir es de treinta días (que obviamente no es igual que el plazo de un mes) y el plazo para resolverlo es de tres meses que es el general de la LPAC. En principio la instrucción y tramitación de los procedimientos en vía de recurso por el TAD no difiere de lo previsto en la LPAC. Sin embargo el apartado 5 del art. 40 de la Ley Orgánica 3/2013 introduce confusión al referirse a especialidades que realmente no lo son. No pueden considerarse «especialidades» que el plazo máximo para dictar y notificar la resolución es de tres meses, a contar desde la fecha 
en que el escrito de iniciación tenga entrada en el registro del TAD; que transcurrido dicho plazo sin resolución expresa, los interesados podrán entender desestimado el recurso; o que el TAD decidirá cuantas cuestiones plantee el procedimiento, hayan sido o no planteadas por los interesados, si bien en este último caso les oirá previamente. Sí puede considerarse una particularidad respecto de las reglas generales la legitimación que se reconoce en materia de dopaje pues, además de al deportista o sujeto afectado por la resolución y la eventual parte contraria en la resolución o los perjudicados por la decisión, también la ostentan la Federación deportiva internacional correspondiente; al organismo antidopaje del país de residencia del sujeto afectado; la Agencia Española de Protección de la Salud en el Deporte; la Agencia Mundial Antidopaje; y el Comité Olímpico Internacional o el Comité Paralímpico Internacional cuando la resolución afecte a los Juegos Olímpicos o Juegos Paralímpicos. Todos podrán interponer el recurso ante el TAD primero y ante la jurisdicción contencioso-administrativa después (artículos 40. 4 Ley Orgánica 3/2013 y 19. 5 LJCA).

Las resoluciones del TAD se ejecutarán por la Federación deportiva que proceda y agotan la vía administrativa, siendo sólo susceptibles de recurso contencioso-administrativo según disponen los artículos 84.4 de la Ley del Deporte y 40. 5. c) de la Ley Orgánica 3/2013). El artículo 10 del Real Decreto 53/2014 puntualiza que no cabe el recurso de reposición. Este precepto reglamentario ha sido criticado al considerar que no cabe que un reglamento excluya el recurso de reposición que, aunque sea potestativo, procede contra los actos que agotan la vía administrativa de acuerdo con la legislación administrativa del procedimiento administrativo común ${ }^{35}$. Comparto esta crítica respecto de las resoluciones que dicta el TAD después de incoar e instruir un expediente sancionador contra los directivos federativos pues efectivamente se impide a los interesados interponer el recurso potestativo de reposición, obligándoles a acudir necesariamente a la jurisdicción contencioso-administrativa. En tal caso, a mi juicio, debe estarse a lo previsto en la LPAC y admitirse el recurso potestativo de reposición contra la resolución del TAD en primera instancia. Pero este planteamiento no es aplicable a las resoluciones que dicta el TAD en vía de recurso. La vigente LPAC, como la anterior Ley 30/1992, impide dos recursos administrativos seguidos y, salvo que concurran los motivos del recurso extraordinario de revisión, las resoluciones de los recursos de alzada y de reposición no son susceptibles de ningún recurso administrativo

$35 \quad$ Así lo pone de relieve el dictamen del Consejo de Estado de 23 de enero de 2014, relativo al Proyecto de Real Decreto por el que se desarrolla la composición, organización y funciones del Tribunal Administrativo del Deporte, en relación con el régimen de recurso contra sus resoluciones consideraba que «se entiende que la Ley Orgánica 3/2013 (artículo 40 in fine) no ha eliminado la posibilidad de que se interponga recurso de reposición contra dichas resoluciones, por lo que se sugiere su inclusión en este precepto del Proyecto». Al respecto A. Palomar Olmeda, «El Tribunal...», cit., pág. 130, considera que «tanto desde la perspectiva de la pura legalidad como desde la oportunidad la medida de supresión del recurso de reposición se presenta como una opción normativa más que discutible». 
de acuerdo con los artículos 122.3 y 124. 3 LPAC, luego sólo cabe acudir a la jurisdicción contencioso-administrativa para impedir la firmeza del acto. Este mismo régimen resulta de aplicación cuando se han sustituido los recursos ordinarios al amparo del artículo 112. 2 LPAC. Por tanto, las resoluciones de los órganos colegiados resolviendo los recursos que los sustituyen tampoco pueden ser recurridas de nuevo en vía administrativa. En consecuencia, es plenamente conforme con la legislación de procedimiento administrativo común que las resoluciones dictadas por el TAD en vía de recurso sólo puedan ser recurridas ante la jurisdicción contencioso-administrativa. Otro tema es que este régimen sea el más eficaz ante la brevedad de los plazos y la complejidad de las cuestiones a resolver en vía de recurso.

De lo anterior puede concluirse que se cumplen todos los parámetros que el artículo 112. 2 LPAC ha previsto para sustituir los recursos administrativos ordinarios: el TAD es un órgano colegiado ajeno al sometimiento jerárquico, que resuelve las reclamaciones que se deduzcan en materia de dopaje, disciplina deportiva y proceso electoral. Y aunque con carácter general el procedimiento ante el TAD sí respeta los principios y garantías generales de los interesados en los procedimientos administrativos, no siempre aplica los plazos previstos en la LPAC, que se reducen sensiblemente ante la especificidad de la materia, que también justifica la inmediata ejecutividad de las sanciones disciplinarias y deportivas como regla general. No obstante hubiera sido deseable que la LPAC incluyera los procedimientos en materia deportiva en su disposición adicional primera aclarando que, como el tráfico y la seguridad vial, la extranjería y el asilo, se rigen por su normativa específica aplicando supletoriamente la legislación de procedimiento administrativo común, en coherencia con lo que establece la propia legislación deportiva.

\section{EL TRIBUNAL ADMINISTRATIVO DEL DEPORTE EN ANDA- LUCÍA, ¿SUSTITUCIÓN DE LOS REGURSOS ADMINISTRA- TIVOS ORDINARIOS?}

\section{Creación, naturaleza jurídica y puesta en funcionamiento}

La Ley 5/2016, de 19 de julio, del Deporte de Andalucía establece un nuevo marco jurídico regulador del deporte de competencia autonómica, derogando la anterior Ley 6/1998, de 14 de diciembre ${ }^{36}$. Uno de los cambios de mayor relevancia es la creación del Tribunal Administrativo del Deporte de Andalucía (en adelante, TADA), que «es el superior órgano administrativo de solución de conflictos deportivos en Andalucía en el ámbito competitivo, disciplinario y electoral federativo, así

36 Puede verse, con carácter general, Comentarios a la nueva Ley del Deporte de Andalucía, Reus, 2017. 
como en cuantas materias de resolución de recursos administrativos contra actos de las federaciones deportivas andaluzas dictados en el ejercicio de funciones públicas de carácter administrativo y tipo sancionador le sean atribuidas conforme a esta ley, al igual que en el ámbito de las soluciones de conflictos deportivos mediante arbitraje» (artículo 146. 1 de la Ley). En la exposición de motivos de la Ley se destaca la amplitud de sus funciones en la resolución de todos los conflictos deportivos:

«Para concluir el título IX, dedicado a la solución de litigios deportivos, circunstancia connatural e intrínseca a cualquier competición o actividad deportiva, es un título novedoso en cuanto a la creación de un órgano único e independiente para la resolución de todas las cuestiones controvertidas: el Tribunal Administrativo del Deporte de Andalucía. Ello supone, de cara a los distintos agentes del deporte y a la ciudadanía en general, tener como referente claro y único un órgano a quien dirigirse para resolver los conflictos que se susciten de carácter sancionador, disciplinario, de resolución de recursos en el ejercicio de funciones públicas de carácter administrativo, de control de legalidad de los procesos electorales federativos, así como para la conciliación de conflictos deportivos mediante la vía arbitral o la mediación».

Quizá esta importancia que para el legislador tiene el TADA explique que se cree dos veces, en el artículo 19 y en el artículo 111.4, con un contenido similar ${ }^{37}$. Sin embargo sorprende que esta relevancia no se haya visto reflejada en el procedimiento de elaboración de la ley ni su articulado haya prestado atención a una cuestión clave como la composición y el estatuto jurídico de sus miembros ${ }^{38}$. En todo caso, lo cierto

$37 \quad$ El artículo 19 de la Ley establece: «Se crea el Tribunal Administrativo del Deporte de Andalucía como superior órgano administrativo de la Junta de Andalucía en el ejercicio de las potestades consignadas en el artículo 146 de la presente ley», y el artículo 11.4 repite: «Se crea el Tribunal Administrativo del Deporte de Andalucía como superior órgano administrativo de la Junta de Andalucía para la solución de litigios deportivos».. En relación con la organización administrativa del Deporte, puede verse C. Núñez Lozano, «La organización administrativa del deporte en Andalucía», en RAAPn ${ }^{\circ} .95$ (2016), págs. 366-370; así como J. L. Carretero Lestón, «Órganos en materia de deporte (Artículos 14 a 19)» y R. Terol Gómez, «Administración del deporte: competencias y relaciones interadministrativas (arts. 11 a 13)», ambos en Comentarios..., cit., págs. 169-192 y 193 ss respectivamente.

38 En la tramitación parlamentaria sólo se presentaron tres enmiendas relacionadas con el TADA. En primer lugar, la enmienda $n^{\circ}$. 30, presentada por el Grupo Parlamentario Socialista, que proponía añadir una nueva competencia a las inicialmente previstas del siguiente tenor: «Conocer y resolver las cuestiones litigiosas que se sometan a través del sistema arbitral o de mediación», que ha quedado incorporada en la letra i) del artículo 147 de la Ley. En segundo lugar, dos enmiendas presentadas por el Grupo Parlamentario Podemos Andalucía, una relativa a la composición del órgano, («El Tribunal Administrativo del Deporte de Andalucía estará integrado por juristas de reconocido prestigio en el ámbito del deporte, designados por la persona titular de la Consejería con competencia en materia de deporte y asistidos por el personal funcionario de carrera adscrito a la Consejería competente en materia de deporte», Enmienda $\mathrm{n}^{\circ}$. 250); y otra a la duración del mandato ( $\mathrm{El}$ mandato de los miembros del Tribunal Administrativo del Deporte de Andalucía es de cuatro años, renovable por un único mandato», Enmienda nº.251) que no fueron aceptadas. 
es que la legislación deportiva andaluza se suma así a la tendencia antes destacada de denominar tribunal al órgano administrativo competente para resolver los recursos deportivos, si bien, como se verá, el TADA asume muchas más competencias. Es un órgano administrativo de naturaleza colegiada adscrito a la Consejería competente en materia de deporte, la Consejería de Turismo y Deporte según el Decreto 212/2015, de 14 de julio. Sus resoluciones agotan la vía administrativa según el artículo 146. 2 de la Ley y, por tanto, en principio, podrán ser recurridas en potestativamente en reposición o directamente ante la jurisdicción contencioso-administrativa. No obstante, cuando actúe en vía de recurso, habría que entender que está sustituyendo a los recursos administrativos ordinarios con el alcance previsto en el artículo 112. 2 LPAC, luego no sería admisible un segundo recurso administrativo.

Sin perjuicio de lo anterior, la puesta en funcionamiento del TADA determinará la supresión del Comité Andaluz de Disciplina Deportiva ${ }^{39}$. También asume, como se verá, las funciones de la Junta de Conciliación del Deporte Andaluz, aunque este órgano no llegó a crearse.

El legislador ha sido consciente de los relevantes cambios que supone la creación del TADA y así lo refleja su Disposición final quinta que retrasa la entrada en vigor del Título IX a los dieciocho meses desde la vigencia de la Ley, que se ha producido al mes de su publicación en el Boletín Oficial de la Junta de Andalucía de 22 de julio de 2016. En consecuencia, hasta febrero de 2018 hay plazo suficiente para la aprobación del reglamento de desarrollo que concrete las escasas previsiones legales. Desde el 24 de enero al 13 de febrero de 2017, se sometió a consulta ciudadana previa el «Proyecto de decreto por el que se regula el título IX de la Ley 5/2016, de 19 de julio, del Deporte de Andalucía, "solución de litigios deportivos"»" ${ }^{40}$ Pero no se ha publicado un texto completo y articulado sino unas líneas con referencias sumamente genéricas a las características generales de la Ley, limitándose a recoger sus previsiones sin ninguna concreción o aclaración. Lo único de interés es que, según se anuncia, se regularía en un mismo reglamento el TADA, el procedimiento sancionador y disciplinario adaptándolo a las nuevas leyes estatales 39 y 40 de 2015 y la inspección deportiva. De esta forma, parece que tendría el mismo contenido que el

En relación con el largo y complejo proceso de elaboración de la nueva Ley, puede verse F. L. López Bustos, «La nueva Ley del deporte de Andalucía: génesis y tramitación parlamentaria», en Comentarios...., cit., 2017, pág. 61 ss.

39 Puede verse P. Escribano Collado, «El Comité Andaluz de Disciplina Deportiva, competencias y funciones: el Comité como órgano consultivo», en Anuario Andaluz de Derecho Deportivo, no . 1, (2001), págs. 2332; y, A. Millán Garrido, «El Comité Andaluz de Disciplina Deportiva», en El régimen sancionador del deporte en Andalucía: potestad sancionadora y potestad disciplinaria en la Ley 6/1998, de 14 de diciembre, del Deporte, 1999, págs. 141-198.

40 La publicación sometida a consulta estuvo disponible en http://www.juntadeandalucia.es/ servicios/participacion/normativa/ consulta- previa/ detalle/102685.html. 
vigente Decreto 236/1999, de 13 de diciembre, del Régimen Sancionador y Disciplinario Deportivo, que quedaría derogado.

\section{Composición, organización interna y funcionamiento}

El TADA, como el actual Comité Andaluz de Disciplina Deportiva, estaría adscrito a la Consejería de Turismo y Deporte a través de la Secretaría General para el Deporte según dispone el artículo 6. 4 del Decreto 212/2015, de 14 de julio, que facilitará el apoyo técnico y de gestión necesario ${ }^{41}$. Y, como el Comité, en el ejercicio de sus funciones actuará «con total autonomía, no estando sometido jerárquicamente a ningún otro órgano de la Administración de la Comunidad Autónoma» según proclama el artículo 146. 2 de la Ley. Desde este planteamiento general, en principio el TADA sería un órgano colegiado de expertos: sus miembros actúan al margen de la subordinación jerárquica, y son designados por las cualidades personales que acreditan para que aporten sus conocimientos, saberes o experiencias en la formación de la voluntad administrativa ${ }^{42}$. Sin embargo, que se reconozca en la Ley su autonomía funcional y la ausencia de sujeción jerárquica debe ser confrontado con la efectiva regulación de su composición, y con la forma de designación y destitución de sus miembros pues, como se adelantó, esa autonomía funcional puede quedarse en una mera declaración formal sino se acompaña con una normativa que efectivamente la garantice. Y poco puede concluirse a este respecto. La regulación que establece la Ley del Deporte es sumamente parca, remitiendo hasta en cuatro ocasiones al reglamento: respecto de la composición (art. 148. 1), de la estructura (art. 148. 2), de los miembros (art. 150. 2) y de la constitución y el funcionamiento (art. 151. 2) ${ }^{43}$. El legislador andaluz ha seguido el mismo criterio que el legislador estatal que remitió la regulación

${ }^{41}$ Con esta intención el artículo 148. 3 de la Ley dispone que «para el desarrollo y ejecución de los cometidos que le corresponden, el Tribunal Administrativo del deporte de Andalucía contará con una unidad diferenciada de carácter administrativo de apoyo y de gestión adscrita a la Consejería competente en materia de deporte conforme a lo que se determine en su relación de puestos de trabajo».

42 El artículo 20 de la Ley 9/2007, de 22 octubre, de Administración de la Junta de Andalucía se refiere a los órganos colegiados de participación administrativa o social como aquellos en «cuya composición se integran, junto a miembros de la Administración de la Junta de Andalucía, representantes de otras Administraciones Públicas, personas u organizaciones en representación de intereses, legalmente reconocidos, o personas en calidad de profesionales expertos». No obstante, los órganos de expertos son distintos de los representativos pues la condición de miembro está vinculada con una determinada titulación, conocimiento, experiencia o saber que se considera necesaria para una adecuada valoración del interés público; no representa otro tipo de intereses aunque hayan podido ser designados por asociaciones u organizaciones científicas o profesionales. Sobre los órganos de expertos, y sus diferencias respecto de los órganos representativos de intereses profesionales o sociales puede verse E. Carbonell Porras, Los órganos colegiados (organización, funcionamiento, procedimiento y régimen jurídico de sus actos), 1999, págs. 45-51.

43 El Consejo Consultivo (Dictamen 440/2014) puso de manifiesto las continuas e innecesarias remisiones al reglamento que efectuaba el Anteproyecto de Ley teniendo en cuenta la potestad reglamentaria originaria del Consejo de Gobierno y la genérica remisión contenida en la disposición final primera. 
de la composición del TAD al reglamento ${ }^{44}$. Si efectivamente se pretende asegurar la imparcialidad e independencia funcional de un órgano administrativo, debe ser la Ley, y no la propia Administración, la que limite y condicione quiénes pueden ser miembros del órgano y cómo se nombran o destituyen. Sólo fijando concretas reglas en la Ley se condicionará la amplísima discrecionalidad de la Administración en el desarrollo reglamentario, asegurando la pretendida autonomía funcional del órgano desde su inicio. La ausencia de reglamento impide ahora un análisis definitivo, aunque sí pueden avanzarse unas consideraciones generales con apoyo en lo que sí dice la Ley. Así se intenta a continuación.

Centrándonos en su composición, el artículo 148.1 de la Ley del Deporte establece que el TADA estará integrado por un número de miembros no inferior a nueve ni superior a trece. Se produce así una ampliación respecto de los actuales integrantes del Comité Andaluz de Disciplina Deportiva (nueve), manteniéndose también un mayor número de miembros respecto del Tribunal estatal (siete) que se justificaría en la ampliación de funciones del nuevo TADA ${ }^{45}$. Corresponde al Consejero de Turismo y Deporte la designación según dispone el artículo 150. 1 de la Ley, sin bien el artículo art. 4. 2. ñ) del Decreto 212/2015 atribuye a la Viceconsejería, la gestión de los nombramientos correspondientes a los órganos colegiados dependientes de la Consejería o aquellos otros en los que forme parte, conforme a la normativa específica.

De acuerdo con el artículo 150. 1 de la Ley, el nombramiento, que deberá respetar la paridad establecida en la legislación vigente, se realizará entre el personal funcionario de carrera adscrito a la Consejería y entre juristas de reconocido prestigio en el ámbito del deporte ${ }^{46}$. De esta escueta regulación sólo se deduce que se trataría

${ }_{44}$ El artículo 84.2 de la Ley 10/1990 se limita a indicar que «su composición, organización y funciones se desarrollarán reglamentariamente, bajo los criterios de mayor simplificación y reducción del gasto posible. En todo caso, en su composición se garantizará el cumplimiento del principio de presencia equilibrada de mujeres y hombres, salvo por razones objetivamente fundadas, debidamente motivadas». En consecuencia, debe estarse a lo previsto en el Real Decreto 53/2014, de 31 de enero, por el que se regula la composición, organización y funciones del Tribunal Administrativo del Deporte.

45 Sobre este dato ha llamado la atención E. Arnaldo Alcubilla, «El Tribunal...» cit., pág. 96. Las funciones que hasta ahora ha ejercicio el Comité Andaluz de Disciplina Deportiva son similares a las del Tribunal estatal, salvo en la función consultiva que este último no ejerce. Según la web (http://www. juntadeandalucia.es/turismoydeporte/opencms/areas/deporte/disciplina-deportiva/resoluciones-comiteandaluz-disciplina-deportiva/), el Comité Andaluz resolvió 221 expedientes en el ejercicio 2016, de los que 88 fueron disciplinarios, 97 electorales, 34 informes y dos consultas. Ese mismo año el TAD resolvió casi 1000 expedientes.

46 De acuerdo con el artículo 18.2 de la Ley 9/2007, de 22 de octubre, de Administración de la Junta de Andalucía «se entiende por representación equilibrada aquella situación que garantice la presencia de mujeres y hombres al menos en un cuarenta por ciento», y resulta de aplicación a los órganos colegiados según el articulo 19 de la misma Ley que fija reglas para su efectivo cumplimiento en la designación de sus miembros. 
de un órgano colegiado en el que sus miembros pueden ser funcionarios de la propia Consejería (que sería la principal diferencia respecto de lo previsto para el Comité Andaluz y el TAD estatal) y externos, y, respecto de éstos últimos, se exige que sean juristas de reconocido prestigio en el ámbito del deporte. Tan parca regulación casa mal con la relevancia que se ha pretendido dar a la creación del TADA y no asegura la pretendida autonomía funcional de sus resoluciones: se admite el nombramiento de quienes son funcionarios de la misma Consejería y, consecuentemente, sujetos jerárquicamente a título individual; nada se indica sobre la titulación o el grupo exigible a los funcionarios; no se concreta qué se entiende por reconocido prestigio en el deporte ni se condiciona mínimamente sobre quién puede recaer el nombramiento; ni se establece un determinado porcentaje de los miembros externos respecto de los funcionarios Tampoco se han previsto unas causas de destitución que garanticen que los miembros decidan según su saber y experiencia, limitando el poder de destitución de quién los nombró. La contradicción del legislador es evidente: todo el sistema de resolución de litigios deportivos y el ejercicio de potestades aflictivas gravita sobre el TADA pero no se han fijado unas pautas que aseguren una composición de expertos, no sujetos a instrucciones jerárquicas ni destituibles libremente; ¿puede reconocerse autonomía funcional a un órgano colegiado si sus miembros son funcionarios que dependen jerárquicamente de quién los designa o pueden ser separados libremente?. Si el número de funcionarios son mayoría, dominando las resoluciones del TADA, tanto en sesiones plenarias como en las de las secciones, podría predeterminarse su contenido en el sentido defendido por el Consejero, obligando a los miembros externos a formular continuos votos particulares para salvar su prestigio, su conocimiento y su experiencia (que en teoría explicaría su condición de miembro del TADA), así como su responsabilidad personal ${ }^{47}$.

El perfil funcionarial previsto para algunos miembros del TADA (o todos pues nada concreta la Ley al respecto) se ha vinculado con el ejercicio de las potestades sancionadoras y disciplinaria que se atribuyen al órgano colegiado pues, como es sabido, «el ejercicio de las funciones que impliquen la participación directa o indirecta en el ejercicio de las potestades públicas o en la salvaguardia de los intereses generales del Estado y de las Administraciones Públicas corresponden exclusivamente a los funcionarios públicos» según dispone el artículo 9.2 del Real Decreto Legislativo 5/2015, de 30 de octubre, por el que se aprueba el texto refundido de la Ley del

47 Como los órganos colegiados forman la voluntad administrativa integrando la individual de sus miembros, se suele afirmar que no actúan sujetos a instrucciones jerárquicas de los órganos superiores de la Administración que, a lo sumo, podrán condicionar la de algún miembro que de ellos dependa, pero no la de los demás. Si todos los miembros o la mayoría tienen un superior jerárquico común no tendrá mucho sentido atribuir la competencia resolutoria al órgano colegiado. De todo ello me he ocupado con detalle en Los órganos colegiados...., cit, págs. 64-66 y «Articulo 22» cit., pág. 176. 
Estatuto Básico del Empleado Público ${ }^{48}$. Por eso, en mi opinión, la condición funcionarial debe exigirse en todo caso al Secretario en atención a las funciones que el ordenamiento jurídico le atribuye vinculadas con el ejercicio de la fe pública ${ }^{49}$. Nada dice tampoco la Ley al respecto. Y, en todo caso, es suficiente con exigir la condición de funcionario público, y no que lo sea de la misma Consejería. La pretendida autonomía funcional del TADA en la adopción de sus resoluciones puede resultar cuestionada si los miembros funcionarios de la Consejería son mayoría, y, consecuentemente, todos ellos dependen jerárquicamente del Consejero que los ha designado. Y la atribución a este órgano de la potestad sancionadora no lo justifica ni, como en su momento se dirá, parece razonable.

La variedad de funciones que se encomiendan al TADA se ha tenido en cuenta por la Ley en las escasas previsiones sobre su estructura interna. Es un órgano colegiado complejo que podrá funcionar en pleno, con todos sus miembros, y en secciones; y, de entre los miembros y en sesión plenaria, se elegirán al Presidente, tres Vicepresidentes y la Secretaria según disponen los artículos 148 y 150. 4 de la Ley. La creación de secciones tendría como finalidad facilitar el funcionamiento del órgano con menos miembros en los términos que precise el reglamento. En la actualidad, el Cómite Andaluz de Disciplina Deportiva cuenta con dos vicepresidencias, una para asuntos disciplinarios, y otra para asuntos electorales (art. 73 del Decreto 236/1999). No obstante, teniendo en cuenta la amplitud de funciones que asumirá el nuevo órgano administrativo no resulta sencillo prever cuáles pueden ser las vicepresidencias y las secciones que se creen, ni siquiera si las vicepresidencias del órgano plenario asumirán también la presidencia de las diferentes secciones o la misma podrá recaer sobre cualquier miembro; ni si el Secretario que, como se indicó, sí debería ser en todo caso un funcionario, lo será del pleno y de las diferentes secciones. Sin perjuicio de lo que después se dirá sobre las diferentes competencias atribuidas al TADA, cabe aventurar que se mantendría el reconocimiento de dos secciones dedicadas, una, a resolver cuantas cuestiones se planteen en los procesos electorales federativos, que se justificaría en la especialidad de la materia; y, otra, a conocer y resolver de los recursos que se deduzcan contra los actos de las federaciones deportivas, las entidades

48 Vid. E. Gamero Casado, «El tribunal...», cit., pág. 923-924.

49 La necesidad de que los secretarios de los órganos colegiados sean funcionarios públicos ha sido destacada por la doctrina. Vid, entre otros, L. Cosculluela Montaner, «Los órganos administrativos: particular referencia a los órganos colegiados» en Comentario sistemático a la Ley de Régimen Furídico de las Administraciones Públicas y del Procedimiento Administrativo Común, 1993, pág. 93; J. Valero Torrijos, Los órganos colegiados Análisis histórico de la colegialidad en la organización pública española y régimen jurídico-administrativo vigente, 2002, pág. 518 ss; o, R. Pizarro Nevado, «Disposiciones generales, principios de actuación y funcionamiento del sector público», en El nuevo régimen jurídico del sector público, 2016, pág. 67. 
deportivas y demás órganos u organismos de la Administración autonómica ${ }^{50}$. Por otra parte es previsible que se cree una sección diferenciada para ejercer las nuevas potestades sancionadora y disciplinaria que, en su caso, permitiría articular la «debida separación entre la fase instructora y la sancionadora que se encomendará a órganos distintos» que exige el artículo 63 de la Ley 39. Esta parece ser la finalidad del artículo 149 de la Ley del Deporte al establecer que «en los procedimientos que así lo requieran, se designará por la Presidencia, de entre quienes integren el Tribunal Administrativo del Deporte de Andalucía y conforme a un turno preestablecido, un instructor o instructora que no formará parte de la sección correspondiente para su resolución» ${ }^{51}$.

Por último, el artículo 140. 2 de la Ley establece que el mandato de los miembros será de cuatro años, renovable, aunque en el plazo máximo de permanencia en el órgano será de dos mandatos consecutivos. Nada ha dispuesto la Ley para garantizar la permanencia en el cargo de los miembros, que podrían ser destituidos libremente por el Consejero si el reglamento no lo remedia.

En definitiva, la indeterminación de la Ley del Deporte no permite afirmar sin margen de duda que el TADA sea un órgano de expertos, ajenos a la subordinación jerárquica que caracteriza la organización administrativa. Habrá que esperar a la regulación reglamentaria para confirmar o no que efectivamente se trata de un órgano de especialistas que actúa con autonomía funcional en la adopción de sus decisiones.

En relación con el régimen de funcionamiento, el artículo 151.1 de la Ley se limita a indicar que «en el ejercicio de sus funciones, el Tribunal Administrativo del Deporte de Andalucía se someterá a las disposiciones contenidas en esta ley y en sus normas de desarrollo, a las de la Ley 30/1992, de 26 de noviembre, y a las establecidas en la Ley 9/2007, de 22 de octubre», reiterando, en el apartado 2, que «se regulará, en desarrollo de lo previsto en esta ley, su constitución y funcionamiento». Naturalmente en la actualidad debe entenderse que la remisión se efectúa a la Ley 39/2015, del Procedimiento Administrativo Común de las Administraciones Públicas y a la Ley 40/2015, del Régimen Jurídico del Sector Público. Como cualquier órgano administrativo, el TADA está sujeto a lo previsto en la legislación estatal sobre el procedimiento administrativo común en la LPAC y, como todos los órganos

50 Así lo confirma el artículo 62. e) de la Ley del Deporte que se refiere a la competencia de la Consejería competente en materia de deporte para resolver los recursos «a través de la sección correspondiente del Tribunal Administrativo del Deporte de Andalucía».

51 Esta es la solución prevista en el artículo 61 de la Orden de 6 de marzo de 2000 para el Comité Andaluz de Disciplina Deportiva y en el Real Decreto 159/1991, de 23 de diciembre sobre disciplina deportiva, para el TAD. 
colegiados, al específicamente destinado a formar la voluntad colegiada ${ }^{52}$. El régimen jurídico básico de los órganos colegiados se establece en la actualidad en los artículos 15 a 18 de la LRJSP, que mantiene una línea de continuidad con lo previsto en la Ley 30/1992, y se completaría con la regulación sobre órganos colegiados que establecen los artículos 88 a 96 de la Ley 9/2007, de 22 de octubre, de la Administración de la Junta de Andalucía ${ }^{53}$. La ausencia de un reglamento que, en su caso, regule el funcionamiento del TADA, exime ahora de analizar el régimen de convocatoria, de celebración de sesiones o de adopción de acuerdos previsto en la legislación estatal básica y en la autonómica de desarrollo que resulta de aplicación general para todos los órganos colegiados de la Junta de Andalucía. Sin perjuicio de lo anterior, merece la pena destacar que el artículo 17. 1 de la LRJSP dispone que «todos los órganos colegiados se podrán constituir, convocar, celebrar sus sesiones, adoptar acuerdos y remitir actas tanto de forma presencial como a distancia, salvo que su reglamento interno recoja expresa y excepcionalmente lo contrario ${ }^{54}$. Y no parece que exista motivo alguno que excluya el funcionamiento electrónico del TADA ${ }^{55}$

\section{Las competencias}

\section{A. Generalidades}

El TADA es el órgano administrativo superior de solución de conflictos deportivos en el ámbito competitivo, disciplinario y electoral federativo, que también resuelve los recursos administrativos contra los actos de las federaciones deportivas andaluzas dictados en el ejercicio de funciones públicas y los litigios deportivos me-

$52 \quad$ El procedimiento colegial está destinado a formar la voluntad del órgano colegiado y se inserta en otro procedimiento administrativo, que es el mismo con independencia que la resolución se haya atribuido a un órgano colegiado o unipersonal. Al respecto puede verse E. Carbonell Porras, Los órganos colegiados..., cit., págs. 69-72 y «Artículo 22» en Comentarios a la Ley 30/1992, 2013, págs. 179-180.

53 Sobre las novedades y el nuevo régimen jurídico de los órganos colegiados, vid. Carbonell Porras, «Regulación de los órganos colegiados» en Innovaciones en el procedimiento administrativo común y el régimen jurídico del sector público, 2016, págs. 235-254; J. Valero Torrijos, «Los órganos administrativos», en Tratado de procedimiento administrativo común y régimen jurídico básico del sector público, 2017, págs. 2715-2750; y, R. Pizarro Nevado, «Disposiciones generales, principios de actuación y funcionamiento del sector público», en El nuevo régimen jurídico del sector público, 2016, págs. 63-72.

54 Expresamente sobre la utilización de medios electrónicos en el procedimiento colegial, puede verse, además de las obras citadas en nota anterior, A. Cerrillo i Martínez, Órganos colegiados electrónicos: el uso de las TIC en el funcionamiento de los órganos colegiados de la administración, 2006; y J. M. Trayter Jiménez, «Los órganos colegiados en el momento presente», en REDA, n. 150, (2011), pág. 12 ss.

55 No obstante, hay que ser cauteloso con la pretendida generalización del empleo de las nuevas tecnologías para todas las fases del procedimiento colegial y para todo tipo de órgano colegiado, en particular en lo que se refiere al desarrollo de la sesión, con los correspondientes debates y votaciones. Sobre las dudas que suscita una utilización indiscriminada de las sesiones a distancia en la LRJSP, puede verse E. Carbonell Porras, «Regulación...», cit., págs. 246-251; J. Valero Torrijos, «Los órganos...», cit., págs. 27432745; o R. Pizarro Nevado, «Disposiciones generales...», cit., págs. 56-70. 
diante arbitraje. Tan amplia atribución de funciones que realiza el artículo 146 de la Ley al definirlo parece vincularlo con la resolución de cualquier clase de litigio o conflicto que pueda surgir en el ámbito deportivo, y con cualquier tipo de procedimiento para resolverlo, sin diferenciar, en lo que ahora interesa, entre los de naturaleza jurídico-pública y los de naturaleza jurídico-privada. Con este alcance, se advierte que el Título IX de la Ley, titulado «Solución de litigios deportivos», incluye la regulación del régimen sancionador en materia administrativa (Capítulo II, que comprende una primera sección, sobre la potestad sancionadora deportiva, y una segunda, relativa a las infracciones y sanciones); del régimen disciplinario deportivo (Capítulo II, integrado por la sección primera, sobre el régimen disciplinario deportivo, y la segunda, sobre infracciones y sanciones); de las garantías generales del procedimiento sancionador y disciplinario (Capítulo IV); del arbitraje y la mediación en materia deportiva (Capítulo V); de la inspección deportiva (Capítulo VI); y, por último, del Tribunal Administrativo del Deporte de Andalucía (Capítulo VII). En la misma línea, el artículo 111.2 de la Ley, único que integra el Capítulo I, relativo a las disposiciones generales, se refiere a la solución de litigios deportivos que comprende «el conjunto de procedimientos administrativos» relativos a las potestades sancionadora y disciplinaria; el arbitraje y la mediación en materia deportiva; la resolución de los recursos administrativos contra actos de las federaciones deportivas andaluzas dictados en el ejercicio de funciones públicas delegadas de carácter administrativo; y el control de legalidad de los procesos electorales de las federaciones deportivas andaluzas. Este mismo artículo dispone, en sus apartados 3 y 4, que la inspección deportiva «actuará como instrumento de colaboración en los procedimientos de solución de litigios deportivos»; y, que se crea el TADA «como superior órgano administrativo de la Junta de Andalucía para la solución de litigios deportivos» ${ }^{56}$. De entrada y sin perjuicio de ulteriores precisiones, la Ley del Deporte se refiere a procedimientos administrativos lo que puede hacer pensar en una generalizada aplicación de la legislación administrativa que es la que regula los procedimientos administrativo. Además, se estaría vinculando la inspección deportiva con esos procedimientos de solución de litigios deportivos y al TADA como órgano administrativo autonómico competente para ello. En tal caso, el legislador autonómico incidiría en el permanente debate sobre la progresiva «administrativización» del Derecho Deportivo, ampliando la aplicación del Derecho Administrativo. Sobre todo ello tendremos ocasión de volver al analizar concretas competencias del TADA que, según el artículo 147 de la Ley, son las siguientes:

«a) Ejercer la potestad sancionadora mediante la instrucción del correspondiente procedimiento de conformidad con lo dispuesto en la presente ley.

56 Puede verse J. L. Carretero Lestón, «Solución de litigios deportivos: arbitraje y mediación. Inspección deportiva (arts. 111 y 140 a 145)» en Comentarios..., cit., págs. 749-758. 
b) Conocer y resolver los recursos interpuestos contra los acuerdos adoptados por las federaciones deportivas y, en su caso, por otras entidades deportivas, dictados en el ejercicio de las funciones públicas que las mismas tienen delegadas.

c) Conocer y resolver, en vía de recurso, las pretensiones que se deduzcan respecto de las resoluciones recaídas en los expedientes disciplinarios de naturaleza deportiva tramitados por los órganos disciplinarios federativos y, en su caso, de los demás órganos u organismos de la Administración autonómica, en relación con las competiciones deportivas de carácter oficial.

d) Conocer y resolver respecto de cualquier otra acción u omisión que, por su trascendencia, en la actividad deportiva estime procedente de oficio o a instancia de la Consejería competente en materia de deporte.

e) Conocer y resolver los conflictos que puedan suscitarse entre las federaciones deportivas o sus órganos disciplinarios en el ámbito de la disciplina deportiva.

f) Conocer y resolver los recursos que se presenten contra los acuerdos de los órganos de las federaciones deportivas en materia de elecciones a los órganos de gobierno y representación federativos o de reprobación o moción de censura a sus presidentes.

g) Incoar, instruir y resolver los expedientes disciplinarios deportivos a los miembros de las federaciones deportivas andaluzas, siempre que se sustancien por hechos cometidos por sus presidentes o directivos, de oficio o a instancia de la Consejería competente en materia de deporte.

h) Ser consultado sobre cuestiones de legalidad en asuntos de especial relevancia en la aplicación de las normas deportivas.

i) Conocer y resolver las cuestiones litigiosas que se sometan a través del sistema arbitral o de mediación.

j) Cualquier otra competencia que le sea atribuida o delegada de conformidad con el ordenamiento jurídico».

Con carácter general, resulta claro que el TADA asume mayores funciones que las que corresponden a su homólogo estatal, similares a las que todavía hoy ejerce el Comité Andaluz de Disciplina Deportiva. Afirma al respecto Gamero Casado que esta ampliación «por una parte, refuerza la posición de este órgano en el entramado de la organización deportiva....; y, por otra, representa un rasgo de confianza y, hasta cierto punto, generosidad por parte de la Administración autonómica que de esta manera cede una parte significativa de su intervención en el sector deportivo confiándola a un órgano caracterizado por el principio de participación en el ejercicio de funciones públicas (desde el momento en que en su composición tienen entrada representantes de los operadores deportivos) y dotado de autonomía funcional, de tal 
manera que la Administración autonómica (en cuanto precursora del Proyecto de Ley) se priva voluntariamente de estas relevantes potestades, depositando su ejercicio en este órgano específico que se erige así en la máxima autoridad decisoria con carácter definitivo en el conjunto de funciones delegadas por el Ordenamiento jurídico en las entidades deportivas, así como en el órgano competente para imponer las sanciones administrativas generales en materia de violencia deportiva» ${ }^{57}$. Pero hay que ser cauteloso con el efectivo resultado de este nuevo reparto de atribuciones tanto a la vista de las que se pretenden encomendar al TADA como de la composición de dicho órgano administrativo, pues, como ya se ha señalado, en absoluto queda asegurada la pretendida autonomía funcional. Y, por eso mismo, me parece discutible considerar una muestra de generosidad de la Administración autonómica el atribuir potestades represivas a este órgano colegiado como tendremos ocasión de destacar con posterioridad.

Seguidamente se analizan las competencias del TADA, primero, las que son similares ejerce el Comité Andaluz de Disciplina Deportiva, aunque han sido ampliadas; después, las que serían las nuevas atribuciones de este órgano para la resolución de litigios deportivos.

B. La resolución de recursos contra los actos federativos en el ejercicio de las funciones públicas delegadas

La legislación deportiva ha atribuido a órganos colegiados con autonomía funcional la resolución de los recursos administrativos, incluso antes de que esta posibilidad se contemplara en la legislación general del procedimiento administrativo. En esta misma línea, el artículo 147 de la Ley dispone que el TADA conoce y resuelve los recursos que se interpongan contra los «acuerdos adoptados por las federaciones deportivas y, en su caso, por otras entidades deportivas, dictados en el ejercicio de las funciones públicas que las mismas tienen delegadas» - letra b); y las «resoluciones recaídas en los expedientes disciplinarios de naturaleza deportiva tramitados por los órganos disciplinarios federativos y, en su caso, de los demás órganos u organismos de la Administración autonómica, en relación con las competiciones deportivas de carácter oficial» - letra c). De este modo, la Ley del Deporte de 2016 establecería una competencia general del TADA para conocer en vía de recurso de cualquier acto federativo dictado en el ejercicio de las funciones públicas delegadas, incluida la disciplinaria que era la que con la Ley del Deporte de 1998 ejercía el Comité Andaluz de Disciplina Deportiva. Así lo confirman otros preceptos de la Ley de 2016 como el artículo 60. 5, que dispone que «sin perjuicio de los demás recursos

57 Vid. «El Tribunal Administrativo del Deporte (Artículos 146 a 151)», en Comentarios..., cit., 2017, pág. 910-911. 
procedentes, los actos adoptados por las federaciones deportivas andaluzas, en el ejercicio de las funciones públicas de carácter administrativo, son susceptibles de recurso administrativo ante el Tribunal Administrativo del Deporte de Andalucía»; y el artículo 62. e) que, al relacionar las atribuciones de la Consejería competente en materia de deporte, incluye «la resolución de recursos contra los actos de las federaciones deportivas andaluzas dictados en el ejercicio de funciones públicas de carácter administrativo, a través de la sección correspondiente del Tribunal Administrativo del Deporte de Andalucía ${ }^{58}$. Las funciones de las federaciones andaluzas se regulan en el artículo 60 de la Ley del Deporte de 2016 que, en su apartado 2, relaciona las de carácter administrativo que ejerce por delegación y bajo los criterios y tutela de la Consejería ${ }^{59}$. Entre las funciones delegadas se incluye, además del ejercicio de la potestad disciplinaria, la de calificar y organizar las actividades y competiciones oficiales federadas en Andalucía y la expedición de las licencias deportivas para participar en competiciones oficiales federadas. La resolución de los recursos que proceda contra estas dos últimas, se atribuirían al TADA. Por lo tanto, cuando se produzca la entrada en vigor del Título IX de la Ley y comience a funcionar el TADA, el recurso de alzada ante el Secretario General para el Deporte que debe interponerse contra los actos federativos dictados en el ejercicio de las funciones públicas de carácter administrativo delegadas al que hace referencia el artículo 20 del Decreto 7/2000, quedará sustituido por el recurso ante el TADA.

58 También constituye una novedad destacable la legitimación que ha previsto en el artículo 108 de la Ley al incluir, entre las atribuciones de la nueva a Comisión Andaluza Antidopaje, la de «instar solicitud de revisión ante el Tribunal Administrativo del Deporte de Andalucía, en los términos previstos en esta ley, cuando estime que las decisiones adoptadas en materia de dopaje por los órganos disciplinarios de las federaciones andaluzas no se ajustan a Derecho» - letra d). Con apoyo en este precepto, podrán recurrirse ante el TADA por un órgano colegiado de la propia Administración autonómica las resoluciones federativas en materia de dopaje. Puede verse R. de Vicente Martínez, «Dopaje en el deporte (arts. 102 a 108)», en Comentarios..., cit., págs. 693 ss. El legislador andaluz intenta potenciar el efectivo cumplimiento de la normativa sobre dopaje pues la Administración autonómica reaccionará ante posibles incorrectas actuaciones de las Federaciones autonómicas recurriendo sus resoluciones ante el TADA en línea con la amplia legitimación que reconoce la legislación estatal (artículo 4. 6 de la Ley Orgánica 3/2013, redactado según el Real Decreto-Ley 3/2017, y 19. 5 de la Ley reguladora de la Jurisdicción Contenciosoadministrativa).

59 El artículo 60. 3 de la Ley precisa que la Consejería podrá concretar, de oficio o a petición de la federación deportiva, en el acto de reconocimiento o en las resoluciones correspondientes, qué funciones públicas ejercerá por delegación conforme a diversos criterios (patrimonio y presupuesto; carácter de olímpica/paralímpica o no olímpica/no paralímpica de la modalidad deportiva; número de licencias; estructura e implantación territorial, organización de competiciones; su función social...) de acuerdo con lo que se determine reglamentariamente. El régimen actual lo establece el Decreto 7/2000, de 24 de enero, de Entidades Deportivas Andaluzas. Sobre la nueva Ley puede verse, A Millán Garrido, «Las federaciones deportivas andaluzas (Artículos 57 a 66), en Comentarios..., cit., págs. 475 ss. 
De lo anterior se deduce que la Ley del Deporte ha utilizado la posibilidad de sustituir los recursos administrativos ordinarios por la impugnación que admite el artículo 112. 2 LPAC, (como en los artículos 107.2 de la anterior Ley 30/1992, y 115 de la Ley 9/2007, de Administración de la Junta de Andalucía). En el supuesto ahora estudiado, el recurso de alzada impropio contra los actos federativos cuya resolución correspondía a un órgano unipersonal de la Consejería de Turismo y Deporte quedará sustituido por la impugnación ante un órgano colegiado al que se ha reconocido autonomía funcional (al menos a nivel de principios y sin prejuzgar ahora lo que pueda establecer el reglamento para garantizarla, y excluir el sometimiento jerárquico de los miembros que integren la sección correspondiente en los términos antes señalados). Y la resolución del TADA agotará la vía administrativa como dispone el artículo 146. 2 de la Ley del Deporte, pero no cabrá recurso potestativo de reposición pues, como es sabido, contra la resolución de un recurso de alzada no cabrá otro recurso administrativo que no sea el extraordinario de revisión (art. 122. 3 LPAC, similar al art. 115 de la derogada Ley 30/1992). Lo sorprendente es que la Ley del Deporte - tampoco el Consejo Consultivo lo advirtió - no haya realizado ninguna referencia a la legislación básica de procedimiento administrativo común ni a la autonómica de desarrollo sobre esta sustitución del anterior recurso de alzada, aclarando además que unas resoluciones del TADA serán susceptibles de recurso de reposición potestativo y otras no.

C. La resolución de recursos en los procesos electorales federativos y otras competencias en materia electoral

La configuración del TADA como un órgano colegiado competente en la resolución de recursos se reitera respecto de los procesos electorales federativos, competencia que también ejercen el TAD estatal y el Comité Andaluz de Disciplina Deportiva. Así lo establece el artículo 147. f) de la Ley del Deporte que se refiere a los recursos que «se presenten contra los acuerdos de los órganos de las federaciones deportivas en materia de elecciones a los órganos de gobierno y representación federativos o de reprobación o moción de censura a sus presidentes». En estos supuestos resulta también aplicable lo anteriormente indicado respecto del TADA como órgano de resolución de recursos, manteniéndose la cuestionada «administrativización» de los procesos electorales que inició la ley estatal de $1990^{60}$.

60 La atribución de esta competencia al TAD, seguida también a nivel autonómico, provocó la entrada de la jurisdicción contencioso-administrativa para conocer de las resoluciones dictadas en vía de recurso que se cuestiona si tenemos en cuenta la consideración legal de las federaciones como entidades privadas. Además de la bibliografía general sobre la extensión del Derecho administrativo a lo deportivo antes recogida, puede verse E. Arnaldo Alcubilla, «La naturaleza...», cit., págs. 97-98; y A. Palomar Olmeda, «El Tribunal...», cit, pág. 94 y 118-119. 
Por otro lado, nada dice la Ley de 2016 sobre otras atribuciones relativas a los procesos electorales como la de informar los reglamentos electorales federativos o la de velar por la legalidad de los mismos que sí se reconocen al TAD o al Comité ${ }^{61}$. No obstante, puede deducirse que no existe intención de suprimir dichas funciones del nuevo TADA, que se podría atribuir expresamente al regular los procesos electorales federativos - letra j) - o incluso podría entenderse incluida en la competencia genérica de ser consultado sobre cuestiones de legalidad en la aplicación de la legislación deportiva previstas - letra h) - , ambos del artículo 47. Por eso, como antes se indicó, una de las secciones en las se organizará internamente el TADA estará dedicada previsiblemente a las cuestiones electorales.

\section{La función consultiva}

El TADA será «consultado sobre cuestiones de legalidad en asuntos de especial relevancia en la aplicación de las normas deportivas» según dispone la letra h) del art. 147 de la Ley del Deporte. También el Comité Andaluz ha venido ejerciendo funciones consultivas sobre cuestiones de legalidad que se estimen de especial relevancia o trascendencia para el desarrollo de la actividad deportiva (art. 82 de la Ley del Deporte de 1998), previa consulta de la Junta y de sus entidades dependientes, de las Entidades Locales y las Federaciones Deportivas andaluzas según dispone el artículo 72 del Decreto 236/1999. El reglamento también dispone que el Comité Andaluz de Disciplina deportiva podrá rechazar, mediante acuerdo motivado, las consultas que carezcan de la relevancia o trascendencia requerida, las que se refieran a asuntos sobre los que ya se haya pronunciado o esté conociendo; y que las declaraciones del Comité revestirán la forma de opinión o dictamen según su importancia y serán vinculantes para las Federaciones consultantes y no vinculantes para las Administraciones Públicas ${ }^{62}$. Es previsible que esta regulación se mantenga en el reglamento que desarrolle la Ley del Deporte de 2016, incluso podría pensarse que se cree una sección del TADA para su ejercicio, aunque no parece que lo justifique el escaso volumen de consultas formuladas al Comité ${ }^{63}$.

${ }_{61}^{61}$ La Ley del Deporte de Andalucía de 1998 se refería a la competencia del Comité Andaluz de Disciplina Deportiva relativa al «control de legalidad sobre los procesos electorales a los órganos de gobierno y representación de las federaciones deportivas andaluzas». En su aplicación, la Disposición adicional primera de la Orden de 11 de marzo 2016, que ha regulado el último proceso electoral, dispuso que el Comité debía informar el reglamento electoral federativo aprobado por la Asamblea General antes de que la Dirección General competente lo ratifique de no contrariar la legalidad vigente. Es razonable pensar que en su momento este informe corresponderá al TADA.

62 Sobre esta función consultiva puede verse P. Escribano Collado, «El Comité....», cit., págs. 23-32.

63 Según los datos publicados, las consultas sometidas al Comité han ido progresivamente reduciéndose, de las 17 de 2012 y 7 en 2013, a sólo una o dos en 2014, 2015 y 2016. 
En principio, la función consultiva que corresponde al TADA se centra en cuestione de legalidad y de especial relevancia, diferenciándose, por tanto, de las genéricas funciones consultivas, de asesoramiento o de informe que la Ley del Deporte de 2016 reconoce al Consejo Andaluz de Deporte (art. 17), al Consejo Andaluz de Federaciones deportivas (art. 18) y a la Comisión Andaluza contra la Violencia, el Racismo, la Xenofobia y la Intolerancia en el Deporte (art. 110). La Comisión Andaluza Antidopaje no tiene reconocida la función consultiva en la Ley, aunque podrá atribuirla el reglamento (art. 109).

E. El ejercicio de las potestades sancionadora y disciplinaria

De entre las principales competencias atribuidas al TADA merece especial atención las relativas al ejercicio de las potestades sancionadora y disciplinaria. La Ley del Deporte de 2016, como su antecesora y las demás leyes deportivas estatal y autonómica, parte de la distinción entre la potestad sancionadora, vinculada con el incumplimiento de la normativa deportiva general, y la potestad disciplinaria, derivada de la violación de las reglas del juego o de la competición ${ }^{64}$. Con esta intención, la Ley establece, en el artículo 112. 1, que la potestad sancionadora se ejerce sobre cualquier persona física o jurídica por la comisión de las infracciones tipificadas en el Capítulo II del Título XI «fundamentalmente en relación al control administrativo de las funciones públicas encomendadas a las federaciones deportivas, y a la tramitación y resolución de procedimientos sobre denuncias en materia deportiva»; y, en el artículo 121.1, que la potestad disciplinaria deportiva conoce de las infracciones a las reglas del juego o competición que son «las acciones u omisiones que, durante el curso del juego o competición, vulneren, impidan o perturben su normal desarrollo» y que son infracciones a las normas deportivas generales «las demás acciones u omisiones que sean contrarias a lo dispuesto por dichas normas». Un análisis detenido de la distinción entre ambas potestades y de lo que constituyen realmente sanciones excede de los propósitos de este estudio que tiene por objeto el TADA y sus competencias ${ }^{65}$.

${ }_{64}$ Sobre la Ley de 1998 puede verse M $^{\mathrm{a}}$ A. Torres López, «La potestad sancionadora y el procedimiento sancionador en materia de deporte en la Comunidad Autónoma Andaluza», en Anuario Andaluz de Derecho Deportivo, nº. 1, (2001), págs. 93-114 y en RAAP, n 45, (2002), págs. 121-148, así como El régimen sancionador del deporte en Andalucía: potestad sancionadora y potestad disciplinaria en la Ley 6/1998, de 14 de diciembre, del Deporte, 1999. De la nueva Ley se han ocupado J. M. Cuchi Denia, «El régimen sancionador deportivo (arts. 112 a 120)» y E. de la Iglesia Prados, «El régimen disciplinario deportivo (Artículos 121 a 133)» y «Las garantías generales del procedimiento sancionador y disciplinario (arts. 134 a 139)», en Comentarios..., cit., págs. 759 ss y 803 ss y 871 ss.

65 La sanción administrativa es el castigo previsto por el ordenamiento jurídico para ser impuesto por la Administración como respuesta a una conducta ilegal. No pretende proteger intereses públicos ni reparar los daños a los mismos como otras decisiones de la Administración que también perjudican a los ciudadanos, que no tienen carácter sancionador y, consecuentemente, no están sujetas a las garantías formales y procedimentales del Derecho Administrativo sancionador. Algo de esta distinción está presente 
En relación con el ejercicio de la potestad disciplinaria, el artículo 124. 1 de la Ley del Deporte la reconoce al TADA «en los términos previstos en esta ley y en su normativa de desarrollo» ${ }^{66}$. Hasta ahora el Comité Andaluz de Disciplina Deportiva ha sido competente para la incoación, instrucción y resolución de los expedientes disciplinarios contra los cargos federativos a instancia de la Consejería, como el TAD lo es a instancia del Consejo Superior de Deportes ${ }^{67}$. En principio, la Ley del Deporte de 2016 mantiene esta atribución. Así se deduce del artículo 62. 2. b) de la Ley, que reconoce que corresponde a la Consejería instar del TADA la incoación del procedimiento disciplinario a los miembros de las federaciones y, en su caso, la suspensión cautelar de los mismos; y del artículo 147. g), que reconoce la competencia del TADA para incoar, instruir y resolver los expedientes disciplinarios deportivos a los miembros de las federaciones deportivas andaluzas, siempre que se sustancien por hechos cometidos por sus presidentes o directivos. Lo novedoso en la nueva regulación es

en el artículo 124. 2 de la Ley del Deporte de 2016 que dispone: «No se considerará ejercicio de la potestad disciplinaria deportiva la facultad de dirección del juego, prueba o competición por los jueces o árbitros a través de la mera aplicación de las reglas técnicas de la correspondiente modalidad o actividad deportiva». Por otra parte, tampoco está clara la distinción entre la potestad sancionadora, que recaería sobre cualquier sujeto por la violación del ordenamiento general, de la potestad disciplinaria, que se ejerce sobre determinados sujetos especialmente vinculados con la Administración. Sobre todas estas cuestiones, véase, por todos, M. Rebollo Puig, M. Izquierdo Carrasco, L. Alarcón Sotomayor, y A. Mª Bueno Armijo, Derecho administrativo sancionador, 2010, págs. 57 ss; y, recientemente,. M. Rebollo Puig y M. Izquierdo Carrasco «Derecho Administrativo sancionador: Caracteres generales y garantías materiales», en Derecho administrativo. II Régimen jurídico básico y control de la Administración, 2a ed., 2017, págs. 203-206 especialmente.

66 El ejercicio de la potestad disciplinaria deportiva corresponde, según artículo 124. 1 de la Ley, a los clubes deportivos andaluces sobre sus socios, deportistas directivos, técnicos y administradores, debiendo regular en sus estatutos el sistema disciplinario interno, excepto en aquello que pertenezca al ámbito del derecho privado; a las federaciones deportivas andaluzas sobre las personas y entidades integradas en las mismas, incluyendo a estos efectos a los clubes y sus deportistas, al personal técnico y directivo, a los jueces y árbitros, así como a todas aquellas personas o entidades que de forma federada desarrollen la modalidad deportiva correspondiente en el ámbito autonómico; y al Tribunal Administrativo del Deporte de Andalucía, en los términos previstos en esta ley y en su normativa de desarrollo. Sobre la potestad disciplinaria en la Ley de 2016, puede verse E. de la Iglesia Prados, «El régimen...»,.. cit., págs. 803 ss.

67 Corresponde a la Consejería «instar del Comité Andaluz de Disciplina Deportiva la incoación del procedimiento disciplinario a los miembros de las federaciones y, en su caso, la suspensión cautelar de los mismos» según disponen los artículos 25 de la Ley del Deporte de 1998, 71 del Decreto 236/1999, y 29 del Decreto 7/2000, de 24 de enero, de Entidades Deportivas Andaluzas. El artículo 57. 2 de la Orden de 6 de marzo de 2000, por la que se dispone la publicación del Reglamento de Régimen Interior del Comité Andaluz de Disciplina Deportiva, introduce algo de confusión al referirse a la iniciación a instancia del Secretario General para el Deporte, o de «parte interesada». Pero, como es sabido, los procedimientos sancionadores se inician siempre de oficio, luego habría que entender que el precepto se refiere a las denuncias que, en su caso, formulen los interesados. Tampoco el TAD puede actuar de oficio, sino siempre a instancias del Consejo Superior de Deportes. Así lo ha puesto de relieve E. Arnaldo Alcubilla, «La naturaleza...», cit., págs. 109-110 que, además destaca que se trataría de una potestad disciplinaria subsidiaria de la que pueden ejercer los propios órganos federativos contra sus dirigentes. Vid. también A. Palomar Olmeda, «El Tribunal...», cit., págs. 105-107. 
que el TADA podrá actuar «de oficio o a instancia de la consejería competente en materia de deporte» según dispone expresamente esta letra g). En todo caso, el ejercicio de la potestad disciplinaria contra los directivos federativos correspondería a las propias federaciones deportivas andaluzas - art. 124.2.b). Por lo tanto, el legislador pretendería superar las dificultades e inconvenientes que suscita que sean los propios órganos federativos disciplinarios los que actúen contra sus directivos. Pero, en mi opinión, este fin no justifica que se atribuya a un órgano colegiado como el TADA, y no a los órganos unipersonales de la Consejería, el ejercicio de la potestad. En seguida volvemos sobre este tema. Antes hay que destacar que la Ley del Deporte parece convertir al TADA en el órgano sancionador de la Administración autonómica en materia deportiva.

En efecto, la primera de las competencias que atribuye al TADA la letra a) del artículo 147 es el ejercicio de «la potestad sancionadora mediante la instrucción del correspondiente procedimiento de conformidad con lo dispuesto en la presente Ley». Para concretar el alcance de esta potestad hay que tener en cuenta otros preceptos de la Ley del Deporte: el artículo 62. d) que, entre las atribuciones de la Consejería, incluye «la incoación del procedimiento sancionador en los términos establecidos en la presente Ley»; el artículo 112. 2, que precisa que «el ejercicio de la potestad sancionadora en materia administrativa deportiva corresponde a la Consejería competente en materia de deporte, a través del Tribunal Administrativo del Deporte de Andalucía, en los casos y formas establecidos por esta Ley»; el artículo 108.c), que reconoce que la Comisión Andaluza Antidopaje podrá «proponer la incoación del procedimiento sancionador al Tribunal Administrativo del Deporte de Andalucía en los términos previstos en esta Ley y en sus normas de desarrollo»; o el artículo 110.4, que establece que la Comisión Andaluza contra la Violencia, el Racismo, la Xenofobia y la Intolerancia en el Deporte «podrá instar la incoación de procedimientos disciplinarios y sancionadores ante el Tribunal Administrativo del Deporte de Andalucía, respecto de las decisiones adoptadas por las entidades deportivas en ejercicio de sus funciones delegadas en materia de disciplina deportiva». De lo anterior puede deducirse que el legislador andaluz ha pretendido convertir al TADA en el órgano administrativo competente para el ejercicio de la potestad sancionadora cuando se produzcan las infracciones tipificadas en los artículos 116 a 118 de la Ley, imponiendo las sanciones que procedan de acuerdo con lo previsto en el art. 119 de la Ley. En consecuencia, con la entrada en vigor del Título IX de la Ley del Deporte, el TADA asumirá las competencias sancionadoras que en la actualidad corresponden al Consejero, al Director General y a los Delegados Provinciales de la Consejería de Turismo y Deporte para la imposición de las sanciones por infracciones muy graves, graves y leves respectivamente según dispone el artículo. 4 del todavía vigente Decreto 236/1999, de 13 de diciembre, del régimen sancionador y disciplinario deportivo de Andalucía. 
Gamero Casado cuestiona que se atribuya al TADA una función tan delicada que, además, no casa bien con la configuración de este órgano ${ }^{68}$. En efecto, a mi juicio, no resulta acertado ni coherente con la pretendida naturaleza jurídica del TADA que se le encomiende la potestad sancionadora general o la potestad disciplinaria contra los presidentes y directivos de las federaciones como prevén tanto la Ley estatal como las legislaciones autonómicas. La opción elegida no es, a mi juicio, la más adecuada, y deberían ser los órganos unipersonales de las Administraciones autonómicas (y del Consejo Superior de Deportes) los que instruyan y resuelvan tanto los procedimientos sancionadores como estos procedimientos disciplinarios, sin perjuicio de la ulterior impugnación ante órganos colegiados independientes que resuelvan los recursos conforme a derecho. Con carácter general, la instrucción de los procedimientos sancionadores debe encomendarse a los órganos unipersonales activos de la Administración de la que también dependen los servicios de inspección a los que corresponde la investigación de los posibles ilícitos, atribuyendo la resolución a los órganos superiores o directivos, que son los responsables política y administrativamente. $\mathrm{Y}$ varios son los argumentos que apoyan este planteamiento. Por un lado, la colegialidad no parece compatible con la instrucción eficaz de un procedimiento administrativo en general y menos aún con uno sancionador. Para solventar este problema, el artículo 146 de la Ley del Deporte prevé, como se ha visto, la designación de un instructor, que no sería miembro de la sección a la que correspondería dictar la resolución. De este modo, además, se pretende mantener la separación entre la instrucción y la resolución que exige el artículo 63.1 LRJSP. Esta solución es anómala, pues los miembros de los órganos colegiados no son órganos ni unidades diferenciadas en la estructura organizativa: son personas físicas a las que se les reconocen unos derechos y deberes que están vinculados únicamente con su participación en la formación de la voluntad colegiada ${ }^{69}$. En el caso del TADA los juristas con experiencia en materia deportiva que sean designados miembros del mismo, sólo tienen esta condición y no cuentan con un nombramiento que les habilite para instruir un procedimiento sancionador, dictando los actos administrativos que resulten necesarios para ello; y, si se nombra instructor a un miembro-funcionario de la Consejería de Turismo y Deportes estaría actuando como órgano o unidad administrativa de la propia Consejería. Además, la atribución de las potestades sancionadora y disciplinaria a un órgano colegiado, y no a uno unipersonal, no supone necesariamente una

68 «El Tribunal...», cit., pág. 915-916 considera que la potestad sancionadora debería ejercerse por los órganos indistintos de la Administración territorial, y señala que estas objeciones podrían salvarse por vía reglamentaria atribuyendo la competencia a un sección del tribunal integrada mayoritariamente por funcionarios públicos.

69 Sobre la estructura y las relaciones internas de los órganos colegiados, puede verse E. Carbonell Porras, Los órganos colegiados.., cit., págs. 79 ss. 
ampliación de las garantías exigibles a todo procedimiento sancionador ${ }^{70}$. Y el procedimiento colegial que, como sabemos, debe seguirse para la formación de la voluntad colegiada sí puede entorpecer la adopción de una resolución en plazo. Por otra parte, sin entrar en el complejo debate sobre la naturaleza reglada y obligatoria del ejercicio de las potestades sancionadora y disciplinaria ante la comisión de infracciones, hay que reconocer que siempre existe un cierto margen de discrecionalidad que permite a la Administración valorar en cada caso los medios con los que cuenta para reprimir los ilícitos administrativos ${ }^{71}$. Así resulta claro que corresponde a la Administración decidir si procede abrir un periodo de información o actuaciones previas; o cuando dicta el acto de incoación del procedimiento siempre que no haya prescrito la infracción. Lo mismo puede decirse respecto de los diferentes trámites del procedimiento, incluida la determinación de la sanción que en cada caso proceda. Y esta valoración, dentro de los márgenes legalmente establecidos, debe ejercerla uno de los órganos superiores o directivos de la Administración y, por eso, el ejercicio de la potestad sancionadora es una de las atribuciones generales de los Consejeros según el artículo 26.2.l) de la Ley 9/2007, de 22 de octubre, de la Administración de la Junta de Andalucía. Podrá contraargumentarse que estos escollos se salvarían creando una sección del TADA compuesta exclusiva o mayoritariamente por los funcionarios de la Consejería designados como miembros pero, como se indicó, en tal caso no se trata de un órgano colegiado de expertos ni cabe hablar de autonomía funcional. Se habría creado una estructura aparentemente colegiada para diluir las responsabilidades de los órganos unipersonales de la Consejería, que podrían ejercer las competencias indirectamente a través de las oportunas instrucciones a los funcionarios que de ellos dependen. Por todo lo anterior, me parece sumamente criticable esta atribución de las potestades sancionadoras y disciplinarias al TADA (lo mismo puede decirse en el caso del órgano estatal y respecto de los procedimientos disciplinarios contra los directivos federativos), que sólo debería ser competente para conocer de los recursos que se interpongan contra las resoluciones sancionadoras y disciplinarias con el alcance antes destacado de sustitución de los recursos ordinarios de alzada o potestati-

$70 \mathrm{Al}$ respecto debe tenerse en cuenta que, en todo caso, se trata de un procedimiento administrativo sancionador en el que no se aplican con la misma intensidad las garantías propias del proceso penal; a los funcionarios y autoridades les resulta exigible la objetividad, es decir la ausencia de cualquier motivación o interés personal, pero no la independencia e imparcialidad de los jueces; ni la separación entre la instrucción y la resolución tiene la misma trascendencia. Sobre todo esto es imprescindible M. Rebollo Puig y otros, Derecho...., cit., págs. 462-472; y L. Alarcón Sotomayor, El procedimiento administrativo sancionador y los derechos fundamentales, 2007.

71 Vid. M. Rebollo Puig y otros, Derecho..., cit., en particular pág. 477, que recuerdan que discrecionalidad no es sinónimo de libertad y menos aún de arbitrariedad. También L. Alarcón Sotomayor, «Derecho administrativo sancionador: garantías formales y procedimiento sancionador», en Derecho administrativo..., cit., págs. 225 ss. 
vo de reposición según el órgano superior o directivo al que expresamente se atribuya la potestad sancionadora deportiva.

F. La solución de cuestiones litigiosas a través del sistema arbitral o de mediación

Una de las nuevas competencias que asumirá el TADA según el artículo 147.i) de la nueva Ley es «conocer y resolver las cuestiones litigiosas que se sometan a través del sistema arbitral o de mediación». Ya la Ley del Deporte de 1988 preveía la creación de la Junta de Conciliación del Deporte Andaluz, como órgano adscrito a la Consejería competente, «de conciliación extrajudicial al cual pueden ser sometidas, voluntariamente por las partes las cuestiones litigiosas surgidas entre los deportistas, técnicos, jueces o árbitros, entidades deportivas andaluzas, sus asociados, y demás partes interesadas» ${ }^{72}$. Este órgano, que no ha llegado a crearse, quedaría ahora integrado en el TADA, y quizá constituya otra de sus secciones.

La legislación deportiva, como es sabido, se ha mostrado especialmente preocupada por fomentar la resolución de los litigios deportivos mediante las vías alternativas al tradicional proceso judicial como la conciliación, el arbitraje o la mediación ${ }^{73}$. El ámbito de posible aplicación del arbitraje en la resolución de conflictos deportivos en Andalucía se delimita en el artículo 140 de la nueva Ley que se refiere a los que se planteen «sobre materia de libre disposición conforme a Derecho y que no afecten al ámbito competencial del Sistema Arbitral de Consumo, al régimen sancionador o disciplinario deportivo» ${ }^{74}$. Lo primero que debe elogiarse es que el legislador andaluz haya excluido expresamente el empleo de estos mecanismos cuando se ejercen potestades administrativas, directamente o por delegación, que casan mal con este tipo de procedimientos y en general con las vías alternativas de resolución de conflictos jurídico-administrativos ya constituidos; ni cabe considerar como arbitraje los procedimientos que la legislación deportiva denomina de «revisión bajo el sistema arbitral» anteriormente analizados. Pero, sin perjuicio de lo anterior, surgen numerosos interrogantes sobre el ámbito de aplicación de estos procedimientos: no

72 Sobre este órgano puede verse, J. Rodríguez Ten, «Una aproximación a la resolución extrajudicial de los conflictos deportivos: reclamaciones sobre clasificaciones, calificaciones, ascensos y descensos de los jueces y árbitros deportivos, con especial referencia al fútbol y al ámbito andaluz», en Anuario Andaluz de Derecho Deportivo n. 3, 2003, págs. 123 ss

$73 \mathrm{El}$ arbitraje deportivo es uno de los grandes retos de nuestra legislación deportiva especialmente como mecanismo de solucionar los conflictos entre los sujetos de derecho privado, incluso se ha defendido su aplicación a la disciplina deportiva, que debería ser despublificada como propuso R. Terol Gómez, Las ligas profesionales, 1999, págs. 389 y ss. Más reciente es la monografía de E. de la Iglesia Prados, Derecho privado y deporte: relaciones jurídico personales, 2014, págs. 313 y ss con amplias referencias bibliográficas sobre este debate.

74 J. L. Carretero Lestón, «Solución...», cit., pág.751 pone de manifiesto que la exclusión del régimen sancionador y disciplinario «resulta superflua e innecesaria». 
se precisa si conocerá de los litigios de derecho privado o de derecho público; ni cuáles son los mecanismos alternativos de resolución del conflicto que se admiten. El artículo 140 de la Ley se refiere a la institución del arbitraje pero, en el apartado 4, también «con carácter alternativo» a la mediación; en las letras b) y c) del apartado 2 se alude a «las fórmulas de conciliación o arbitraje» y a las «funciones de conciliación o arbitraje»; en el apartado 5 a la sumisión a «sistemas de arbitraje; o, en definitiva, en el apartado 6 que remite las resoluciones adoptadas por estos procedimientos a lo previsto en la Ley 60/2003, de 23 de diciembre, de Arbitraje. Semejante galimatías deberá resolverse por el reglamento que fijará al menos las siguientes reglas:

a) Método para manifestar la inequívoca voluntad de sumisión de las personas interesadas a dicho sistema.

b) Materias, causas y requisitos de aplicación de las fórmulas de conciliación o arbitraje.

c) Sistema de recusación de quienes realicen las funciones de conciliación o arbitraje, así como de oposición a dichas fórmulas.

d) Procedimiento a través del cual se desarrollarán estas funciones, respetando, en todo caso, los principios constitucionales y, en especial, los de contradicción, igualdad y audiencia de las partes.

e) Métodos de ejecución de las decisiones o resoluciones derivadas de las funciones conciliadoras o arbitrales.

No obstante, como estos mecanismos alternativos de resolución de conflictos están vinculados en principio y con carácter general con los que surgen entre particulares, hay que advertir del riesgo de una nueva «administrativización» de lo deportivo respecto de controversias interprivatos en una Ley que se refiere a los procedimientos administrativos de arbitraje y mediación y que atribuye su resolución a un órgano administrativo que se rige por el Derecho administrativo, como es el TADA.

G. La resolución de conflictos entre federaciones o sus órganos disciplinarios

También corresponde al TADA, según la letra e) del artículo 147, conocer y resolver los conflictos que puedan suscitarse entre las federaciones deportivas o sus órganos disciplinarios en el ámbito de la disciplina deportiva. Parece que el legislador está pensando en los conflictos de atribuciones que puedan suscitarse, no entre los órganos administrativos, sino entre las federaciones y sus órganos con competencias disciplinarias. Gamero Casado ha señalado que caben tres tipos de conflictos: los que se suscitan entre federaciones deportivas respecto de sus propias competencias como, por ejemplo, el reconocimiento de una especialidad deportiva; los que se planteen entre órganos de gobierno y disciplinarios de una misma Federación y los de 
órganos disciplinarios de dos federaciones deportivas como, por ejemplo, un control de dopaje fuera de competición a un deportista con licencia de dos federaciones ${ }^{75}$. A mi juicio, creo que hay que diferenciar los conflictos que puedan enfrentar a dos federaciones vinculados con el ejercicio de las funciones públicas delegadas, de los que surgen en el seno de una misma Federación. En los primeros, sí está justificada la intervención de la Administración autonómica en sus funciones de tutela, si bien, como ya se ha indicado, deberían ser los órganos superiores y directivos de la Consejería los que decidieran, sin perjuicio de que su resolución se recurra ante el TADA Respecto de los segundos, de nuevo existe el riesgo de «administrativizar» cuestiones de organización interna de unas «entidades privadas sin ánimo de lucro» según define a las federaciones el artículo 57 de la Ley.

H. El conocimiento y la resolución de cualquier otra acción u omisión, la atribución de nuevas competencias y el ejercicio de competencias delegadas

El artículo 147. d) de la Ley confiere una última competencia al TADA: la de «conocer y resolver respecto de cualquier otra acción u omisión que, por su trascendencia, en la actividad deportiva estime procedente de oficio o a instancia de la Consejería competente en materia de deporte». Esta atribución es enigmática y de difícil concreción ya que se trata de una competencia resolutiva, no consultiva que, además, puede ejercerse de oficio ${ }^{76}$. Gamero Casado la reconduce a la posibilidad de emitir declaraciones sobre asuntos de interés en materia deportiva fijando su posición ante un eventual litigio deportivo en la que resulte oportuno expresar su parecer ${ }^{77}$.

Delimitar cuales son las acciones y omisiones para las que resultará competente el TADA, de oficio o a instancia de la Consejería, no resulta sencillo, particularmente si tenemos en cuenta que podrá ejercer cualquier otra competencia «que le sea atribuida o delegada de conformidad con el ordenamiento jurídico» - artículo 147. j). En su aplicación, las normas podrán atribuir nuevas competencias al TADA pero también cabe que otros órganos administrativos deleguen el ejercicio de sus competencias propias. Si esto es así, ¿que acción u omisión de trascendencia deporti-

75 «El tribunal...», cit., pág. 920, si bien añade que corresponderá al reglamento la concreción de los conflictos que comprende y su tramitación: si se incoa de oficio por el TADA o a instancia de parte; y qué procedimiento debe seguirse, que podrá contemplar formas alternativas de resolución como la mediación.

76 Vid. E Gamero Casado, «El tribunal...», cit., págs. 922-923, que, con apoyo en la irrenunciabilidad de la competencia, afirma que el TADA «no puede pronunciarse y, mucho menos resolver sobre competencias que el ordenamiento jurídico confie, por vía legal o reglamentaria a otros órganos administrativos o incluso a otras entidades diferentes. Y resulta dudoso que, con fundamento en este precepto, y además de oficio, el Tribunal pueda instar un procedimiento sobre alguna materia que no sea competencia expresa de ningún órgano administrativo». También ha cuestionado esta atribución, C. Núñez Lozano, «La organización administrativa...», cit., pág. 368.

77 «El tribunal...», cit., págs. 922-923. 
va conocerá y resolverá el TADA de oficio o a instancia de la Consejería al margen del régimen general de atribución de nuevas competencias o de la delegación del ejercicio de las atribuidas a otros órganos administrativos?; Hasta el desarrollo reglamentario no parece posible pronunciarse con claridad al respecto. Pero surge la duda de si no se estaría posibilitando que el órgano formalmente competente eluda sus responsabilidades pasando una competencia total o parcialmente al TADA sin recurrir al mecanismo legalmente establecido para ello como es la delegación interorgánica. Y existe un riesgo ya destacado con anterioridad derivado de la creación de una sección dominada por los funcionarios de la Consejería.

\section{ALGUNA REFLEXIÓN FINAL}

La creación del TADA constituye una de las novedades más destacadas de la Ley del Deporte de Andalucía de 2016, que se justifica en la simplificación y eficiencia administrativa al atribuirse a un único órgano administrativo la resolución de todos los litigios deportivos: desde los relativos a las potestades sancionadora y disciplinaria hasta la resolución de los recursos contra los actos federativos en el ejercicio de las funciones públicas delegadas, incluyendo el control de la legalidad de los procesos electorales y el arbitraje y la mediación en materia deportiva. Se han ampliado significativamente las funciones que la legislación anterior (y todavía en vigor) atribuía al Comité Andaluz de Disciplina Deportiva así como las que ejerce el TAD estatal. Esta ampliación podría determinar una «administrativización» de cuestiones hasta ahora ajenas a esta rama del ordenamiento jurídico como las relativas a las relaciones entre sujetos de derecho privado como son las entidades deportivas, y los agentes del deporte de naturaleza no sancionadora y disciplinaria. Así ha ocurrido ya de manera generalizada con los procesos electorales en las Federaciones deportivas. Además tan amplias competencias se justifican en la independencia del TADA, que, como órgano colegiado, actuaría sin sometimiento jerárquico a ningún otro órgano de la Administración autonómica. Y sin embargo nada ha previsto el legislador para asegurar que esa autonomía funcional sea real y efectiva; por el contrario, la escasa regulación legal no apoya este objetivo, cuestionando la pretendida configuración del TADA como órgano de expertos y surge la duda de su posible empleo para diluir la responsabilidad de los órganos unipersonales superiores y directivos de la Consejería. Recordemos ahora que, como agudamente señaló Nieto García, en no pocas ocasiones se crean órganos colegiados injustificados, que diluyen la responsabilidad de los órganos unipersonales de la Administración y provocan la ineficacia de la actuación administrativa: «la realidad es que cuando un director no quiere o no sabe tomar una decisión remite el tema a una comisión a conciencia de que en ella el asunto va a dormitar durante años y de que, al cabo de innumerables aunque espaciadas 
deliberaciones, el resultado será un documento evanescente y retórico, repleto de distingos y matices en el que cada miembro salvará su responsabilidad en una síntesis de compromiso absolutamente inoperante» ${ }^{78}$.

Los órganos colegiados de expertos son aquellos que forman la voluntad colegiada mediante la integración de las opiniones individuales de los miembros que aportan sus conocimientos y saberes técnicos que son los que deben exigirse en el nombramiento; no representan ni defienden intereses de organización alguna, ni siquiera de la propia Administración pública a la que se adscriben por estrictas razones organizativas, no jerárquicas; y, por eso, no pueden ser destituidos libremente. Esta configuración del órgano provoca que la voluntad colegiada no siempre se forme mediante una votación; es frecuente que, después de deliberar, los miembros alcancen un acuerdo y resuelvan por consenso o unanimidad y sin necesidad de votar. Para que realmente funcionen de forma eficaz deben ser pocos los integrantes del órgano y con un estatuto jurídico que asegure que sólo están sujetos a su propio juicio técnico. Si parte de sus miembros están condicionados a título individual a las instrucciones de sus superiores (como sin duda sucede con los funcionarios de una Consejería respecto del Consejero de la misma) puede predeterminarse la decisión del órgano que sólo es colegiada aparentemente. No es aventurado imaginar que los miembros-funcionarios actuarían como un bloque en el sentido defendido por el Consejero, dominando con frecuencia al propio órgano colegiado, y forzando a los miembros realmente independientes a formular continuos votos particulares para salvar su prestigio personal.

La regulación que establece la Ley del Deporte estatal respecto de la composición del TAD es escasa y ha sido el reglamento de desarrollo el que lo ha configurado como un órgano de expertos, con plena independencia en la adopción de decisiones frente a los demás órganos del Consejo Superior de Deportes, asegurando, además, la permanencia en el cargo de los designados. Por eso, el TAD puede considerarse un órgano colegiado no sometido a instrucciones jerárquicas en el sentido del artículo 112. 2 LPAC. Lo mismo podría suceder en Andalucía. Ante las escasas previsiones legales, el reglamento que se dicte en desarrollo del este Título IX de la Ley del deporte de 2016 dispone de una amplísima discrecionalidad para regular la organización del TADA. Por vía reglamentaria pueden corregirse las deficiencias denunciadas y asegurar que efectivamente se trata de un órgano colegiado de especialistas que actúa con autonomía funcional. Tiempo hay si es que realmente se decide ponerlo en funcionamiento.

78 La "nueva" organización del desgobierno, 1996, en particular, pág. 45. 


\section{BIBLIOGRAFÍA}

AUTORES VARIOS: Tratado de Procedimiento Administrativo Común y Régimen Furídico Básico del Sector Público, en E. GAMERO GASADO (dir.) y S. FERNÁNDEZ RAMOS y J. VALERO TORRIJOS (coors.), Tirant lo Banch, Valencia, 2017.

- Comentarios a la nueva Ley del Deporte de Andalucía, A. MILLÁN GARRIDO (dir.), Reus, 2017.

- Informe sobre la fusticia Administrativa 2016. Tributos, Contratos Públicos, Responsabilidad Patrimonial y Derechos Fundamentales, S. DÍEZ SASTRE (dir.) y C. MARTÍNEZ SÁNCHEZ (coor.), Centro de Investigación sobre Justicia Administrativa de la Universidad Autónoma de Madrid, Junio 2016.

- Las vías administrativas de recurso a debate, Actas del XI Congreso de la Asociación Española de Profesores de Derecho Administrativo celebrado en Zaragoza, los días 5 y 6 de febrero de 2016, F. LÓPEZ RAMÓN (coor.), Madrid, Instituto Nacional de Administración Pública, 2016.

- Control administrativo y justicia, J. AGUDO GONZÁLEZ (dir.), Instituto Nacional de Administración Pública, 2016.

-Las prestaciones patrimoniales públicas no tributarias y la resolución extrajudicial de conflictos, Actas del X Congreso de la Asociación Española de Profesores de Derecho Administrativo celebrado en Madrid, los días 6 y 7 de febrero de 2015, F. LÓPEZ RAMÓN (coor.), Madrid, Instituto Nacional de Administración Pública, 2015.

- El régimen sancionador del deporte en Andalucía: potestad sancionadora y potestad disciplinaria en la Ley 6/1998, de 14 de diciembre, del Deporte, en A. MILLÁN GARRDIDO, (dir.), Bosch, 1999.

AGIRREAZKUENAGA ZIGORRAGA, I.: Intervención pública en el deporte, CivitasInstituto Vasco de Administración Pública, Madrid. 1998.

ALARCÓN SOTOMAYOR, L.: «El procedimiento administrativo» y «Derecho administrativo sancionador: garantías formales y procedimiento sancionador», ambos en Derecho administrativo. II Régimen jurídico básico y control de la Administración, M. REBOLLO PUIG y E. CARBONELL PORRAS (coors.), $2^{\mathrm{a}}$ ed., Tecnos, Madrid, 2017.

-El procedimiento administrativo sancionador y los derechos fundamentales, Cizur Menor (Navarra), Thomson-Civitas, 2007.

BERMEJO VERA, J.: Constitución y Deporte, Tecnos, Madrid, 1998. 
ARNALDO ALCUBILLA, E.: «La naturaleza y las funciones del Tribunal Administrativo del Deporte», en Los retos del deporte profesional y profesionalizado en la sociedad actual, I. JIMÉNEZ SOTO y J. L. PÉREZ-SERRABONA GONZÁLEZ (dirs.), 2017.

BUSTILlO BOLADO, R. O.: Convenios y Contratos Administrativos: Transacción, Arbitraje y Terminación Convencional del Procedimiento, Cizur Menor (Navarra), Aranzadi, 2004.

CAMPS POVILL, A.: Las federaciones deportivas: régimen jurídico, Madrid, Civitas 1996.

CARBALLO MARTINEZ, G.: «La mediación administrativa. Algunas propuestas para su implementación en el régimen jurídico administrativo y procesal», en Revista furídica de Castilla y León, no. 29, enero, 2013.

CARBONELL PORRAS, E.: Los órganos colegiados (organización, funcionamiento, procedimiento y régimen jurídico de sus actos), Centro de Estudios Políticos y constitucionales-Boletín Oficial del Estado, Madrid, 1999.

- «El Conflicto interadministrativo local: novedades en la LRBRL y en la LJCA» en Fusticia administrativa $\mathrm{n}^{\circ}$. 1, 2000.

-«Comentario a los artículos 63 a 67», en Comentarios a la Ley Reguladora de las Bases de Régimen Local, M. REBOLLO PUIG (dir.) y M. IZQUIERDO CARRASCO (coor.), II, Valencia, Tirant lo Blanch, 2007.

- «Capítulo II. Órganos colegiados (artículos 22 a 27)», en Comentarios a la Ley 30/1992, en M. SÁNCHEZ MORÓN y N. MAURANDI GUILLEN (dirs.), Lex Nova-Thomson Reuters, Valladolid-Pamplona, 2013.

- «Regulación de los órganos colegiados» en Innovaciones en el procedimiento administrativo común y el régimen jurídico del sector público, en F, LÓPEZ MENUDO (dir.), Editorial Universidad de Sevilla- Instituto García Oviedo, Sevilla, 2016.

- «La organización administrativa. Conceptos, principios y reglas generales», en $D e-$ recho administrativo. II Régimen jurídico básico y control de la Administración, M. REBOLLO PUIG y E. CARBONELL PORRAS (coors.), Tecnos, Madrid, 2016.

-«La resolución de conflictos por vías distintas de los recursos administrativos ordinarios: los ejemplos del deporte y la unidad de mercado», en La mediación como alternativa a la judicialización de asuntos civiles, mercantiles y administrativos, R. CABRERA MERGADO (dir.), Dykinson, Madrid, 2017.

CARBONELL PORRAS, E y MUGA MUÑOZ, J. L.: Agencias y Procedimiento administrativo en Estados Unidos de América, Marcial Pons, Madrid, 1996. 
CERRILLO I MARTÍNEZ, A.: Órganos colegiados electrónicos: el uso de las TIC en el funcionamiento de los órganos colegiados de la administración, Cizur Menor (Navarra), Thomson-Aranzadi, 2006.

CHOZAS ALONSO, J. M.: «El ámbito de la mediación, como mecanismo de autocomposición de las partes en la resolución de conflictos, en la Universidad complutense de Madrid», en Revista Española de Derecho Administrativo n ${ }^{\circ}$ 170, 2015.

COSGULLUELA MONTANER, L.: «Los órganos administrativos: particular referencia a los órganos colegiados» en Comentario sistemático a la Ley de Régimen Jurídico de las Administraciones Públicas y del Procedimiento Administrativo Común, Carperi, Madrid, 1993.

DELGADO PIQUERAS, F.: La terminación convencional del procedimiento administrativo, Cizur Menor (Navarra), Aranzadi, 1995.

ESCARTÍN ESCUDÉ, V.: «El arbitraje y otros medios de resolución de conflictos el derecho administrativo», en Revista Aragonesa de Administración Pública, ns ${ }^{\circ}$. 3940, 2012.

ESCRIBANO COLLADO, P.: «El Comité Andaluz de Disciplina Deportiva, competencias y funciones: el Comité como órgano consultivo», en Anuario Andaluz de Derecho Deportivo, no.. 1, (2001).

GAMERO GASADO, E.: «¿Un sistema arbitral para el dopaje? Consideraciones y alternativas», en Revista Española de Derecho Deportivo, nº 15, 2005.

- «La revisión de las sanciones por dopaje», en Comentarios a la Ley Orgánica de Protección de la Saludy de la Lucha contra el Dopaje en el Deporte en A. MILLÁN GARRIDO, (coor.), Dykinson, Madrid, 2007.

GARCÍA VICARIO, M. C.: «La mediación como sistema alternativo y complementario de resolución de conflictos en la Jurisdicción Contencioso-Administrativa», en Revista furídica de Castilla y León, n. 29, enero, 2013.

GARCÍA PÉREZ, M.: «Luces y sombras del arbitraje institucional en la Administración General del Estado» en Revista Andaluza de Administración Pública, nº 80, 2011.

- Arbitraje y derecho administrativo, Cizur Menor, (Navarra), Aranzadi, 2011

GÓNZALEZ GÓNZALEZ, A.: «La nueva ley andaluza del deporte y su encaje en la legislación antidopaje del Estado: la crónica de un desencuentro», en Revista Aranzadi de derecho de deporte y entretenimiento, n'. 54, 2017. 
HUERGO LORA, A.: Los contratos sobre los actos y las potestades administrativas, Civitas, Madrid, 1998.

- La resolución extrajudicial de conflictos en el Derecho administrativo, Studia Albornotiana 75, Publicaciones del Real Colegio de España, Bolonia, 2000.

IGLESIA PRADOS, E. DE LA: Derecho privado y deporte: relaciones juridico personales, Reus, Madrid, 2014.

LORA-TAMAYO VALLVÉ, M.: El derecho deportivo: entre el servicio público y el mercado, Madrid, Dykinson, 2003.

MASUCGI, A.: «El procedimiento de mediación como medio alternativo de resolución de litigios en el derecho administrativo. Esbozo de las experiencias francesa, alemana e inglesa», en Revista de Administración Pública n’. 178, 2009.

MIGUEZ MACHO, L.: «Autotutela administrativa y tutela judicial efectiva: nuevas perspectivas para el proceso contencioso-administrativo», en Revista General de Derecho Administrativo no 38, 2015.

NIETO GARCÍA, A.:La "nueva" organización del desgobierno, Ariel, Barcelona, 1996.

NÚÑEZ LOZANO, G.: «La organización administrativa del deporte en Andalucía», en Revista Andaluza de Administración Pública nº 95, (2016).

PAREJO ALFONSO, L.: «La revisión administrativa de las sanciones por actos en materia de dopaje», en Comentarios a la Ley antidopaje en el deporte, en L. M ${ }^{\mathrm{a}}$. CAZORLA PRIETO, L. Ma y A. PALOMAR OLMEDA, (coords.), Cizur Menor (Navarra), Aranzadi, 2007.

PIZARRO NEVADO, R.: «Disposiciones generales, principios de actuación y funcionamiento del sector público», en El nuevo régimen jurídico del sector público, en $\mathrm{H}$. GOSÁLBEZ PEQUEÑO (coor.), El Consultor de los Ayuntamientos-Wolters Kluwer, Madrid, 2016.

- «Principios y bases del régimen jurídico de la organización local», en La Ley 40/2015, de 1 de octubre, de Régimen Jurídico del Sector Público y las Administraciones Locales, en H. GOSÁLBEZ PEQUEÑO (dir.), CEMGI, Granada, 2016.

PALMA DEL TESO, A. de: Los acuerdos procedimentales en el Derecho Administrativo, Valencia, Tirant lo Blanc, 2000.

PALOMAR OLMEDA, A.: «El Tribunal Administrativo del Deporte», en Cuestiones actuales de derecho del deporte, en A. MILLÁN GARRIDO (coor.), Reus, Madrid, 2015. 
- El sistema deportivo español: una visión diferente y pautas de reforma, Cizur Menor, (Navarra), Aranzadi, 2011.

PARADA VÁZQUEZ, J. R.: «Arbitraje y derecho administrativo. La actividad arbitral de la Administración», en Revista Galega de Administración Pública, nº. 23, 1999.

- Derecho Administrativo II. Régimen jurídico de la actividad administrativa, $23^{\mathrm{a}} \mathrm{ed}, 1^{\mathrm{a}}$ ed. en Ediciones Academicas, S.A. (EDIASA), 2017.

REAL FERRER, G.: «Aproximación a los nuevos procedimientos para la imposición y revisión de sanciones por dopaje», en El nuevo Derecho deportivo disciplinario, en J. L. CARRETERO LESTÓN (coor). Ediciones Laborum, Madrid, 2009.

- Derecho público del deporte, Madrid, Civitas, 1991.

REBOLLO PUIG, M., IZQUIERDO GARRASGO, M., ALARCÓN SOTOMAYOR, L. y BUENO ARMIJO, A. M ${ }^{\mathrm{a}}$.: Derecho administrativo sancionador, Lex Nova, Valladolid, 2010.

REBOLLO PUIG, M., e IZQUIERDO GARRASCO, M.: «Derecho Administrativo sancionador: Caracteres generales y garantías materiales», en Derecho administrativo. II Régimen jurídico básico y control de la Administración, en M. Rebollo Puig y E. Carbonell Porras (coors.), Tecnos, 2a ed., Madrid, 2017.

RODRÍGUEZ TEN, J.: «Una aproximación a la resolución extrajudicial de los conflictos deportivos: reclamaciones sobre clasificaciones, calificaciones, ascensos y descensos de los jueces y árbitros deportivos, con especial referencia al fútbol y al ámbito andaluz», en Anuario Andaluz de Derecho Deportivo nº 3, 2003.

ROSA MORENO, J.: «Definitiva articulación de la fórmula arbitral en el procedimiento sancionador en materia de dopaje», en Revista Aranzadi de derecho de deporte y entretenimiento, no. 23, 2008.

- El arbitraje administrativo, McGraw-Hill Interamericana de España, 1998.

SÁNGHEZ MORÓN, M.: «Nuevas garantías de Derecho Administrativo», en $R e^{-}$ vista de Administración Pública n$^{\circ}$. 194, 2014

- El control de las Administraciones públicas y sus problemas, Espasa-Calpe, Madrid, 1991.

SÁNCHEZ MORÓN, M., SÁNCHEZ BLANCO , A., y TRAYTER JIMÉNEZ, J. M.: La apertura del procedimiento administrativo a la negociación de los ciudadanos en la Ley 30/1992, de Régimen Furídico del as Administraciones Públicas y del Procedimiento Administrativo Común, Oñati, Instituto Vasco de Administración Pública, 1995. 
SARMIENTO ACOSTA, M.J.: «Fórmulas complementarias de resolución de controversias jurídico-administrativas: acerca de la creación de comisiones o tribunales administrativos», en Revista Andaluza de Administración Pública no . 76, 2010.

SEOANE OSA, J.J.: «El Tribunal Administrativo del Deporte (TAD) y el dopaje», en Revista Aranzadi de derecho de deporte y entretenimiento $\mathrm{n}^{\circ} 43,2014$.

TEJEDOR BIELSA, J. G.: Público y privado en el deporte, Barcelona, Bosch, 2003.

TEROL GÓMEZ, R.: Las ligas profesionales, Cizur Menor, (Navarra), Aranzadi, 1999.

TORNOS MÁS, J.: «Los medios complementarios a la resolución jurisdiccional de los conflictos administrativos», en Revista de Administración Pública nº 136, 1995.

- «El Consell Tributari del Ayuntamiento de Barcelona», en Documentación Administrativa $\mathrm{n}^{\circ} .220,1989$.

TORRES LÓPEZ, M ${ }^{\mathrm{a}}$. A.: «La potestad sancionadora y el procedimiento sancionador en materia de deporte en la Comunidad Autónoma Andaluza», en Anuario Andaluz de Derecho Deportivo, no. 1, 2001; y en Revista Andaluza de Administración Pública, no. 45, 2002.

TRAYTER JIMÉNEZ, J. M.: «Los órganos colegiados en el momento presente», en Revista Española de Derecho Administrativo, n. 150, 2011.

VALERO TORRIJOS, J.: Los órganos colegiados: análisis histórico de la colegialidad en la organización pública española y régimen jurídico-administrativo vigente, Instituto Nacional de Administración Pública-Centro de Estudios Políticos y Constitucionales, Madrid, 2002. 